\title{
Article
}

\section{State of the Art on Heat Pumps for Residential Buildings}

\author{
Zheng Wang, Mark B. Luther*(D), Mehdi Amirkhani (D), Chunlu Liu (D) and Peter Horan
}

School of Architecture and Built Environment, Deakin University, Geelong 3220, Australia; wangzheng@deakin.edu.au (Z.W.); m.amirkhani@deakin.edu.au (M.A.); chunlu.liu@deakin.edu.au (C.L.); peter.horan@deakin.edu.au (P.H.)

* Correspondence: mark.luther@deakin.edu.au

Citation: Wang, Z.; Luther, M.B.; Amirkhani, M.; Liu, C.; Horan, P. State of the Art on Heat Pumps for Residential Buildings. Buildings 2021, 11, 350. https://doi.org/10.3390/ buildings 11080350

Academic Editor: Fabrizio Ascione

Received: 16 July 2021

Accepted: 12 August 2021

Published: 14 August 2021

Publisher's Note: MDPI stays neutral with regard to jurisdictional claims in published maps and institutional affiliations.

Copyright: (c) 2021 by the authors. Licensee MDPI, Basel, Switzerland. This article is an open access article distributed under the terms and conditions of the Creative Commons Attribution (CC BY) license (https:// creativecommons.org/licenses/by/ $4.0 /)$.

\begin{abstract}
Heat Pumps are becoming one of the most considered mechanical conditioning equipment in our buildings. While they are popular, there appears to be quite a vast range of system types and applications in building conditioning. This paper primarily reviews the literature on heat pumps, the various types, and the consideration of design end uses. The fact that there are different energy sources for heat pumps is considered, as well as the different sinks in which energy is stored or dissipated. It is evident that advanced heat pump systems cater well to the use of renewable energy resources. Therefore, in the move towards net-zero energy building operation, the correct selection of a heat pump can help to increase self-consumption of solar PV generation and even make use of direct solar energy heating. This paper reviews the technologies for heat pump selection, application, and design for residential buildings.
\end{abstract}

Keywords: end uses; energy sources; energy storage; heat pumps; residential buildings

\section{Introduction Why Heat Pumps?}

Our world is facing two main problems: energy challenges and climate change [1-3]. The building sector, especially the residential sector, dramatically contributes to energy use and greenhouse gas (GHG) emissions. The residential sector represents $25.4 \%$ of final energy use and 20\% GHG emissions in the European Union (EU) [4,5]. Similarly, in Australia, fossil fuels provide approximately $94 \%$ of the country's energy consumption, and $11 \%$ of the country's total energy consumption is represented by the residential sector [6]. Space heating, cooling, and hot water heating contribute about $65 \%$ of total energy consumption in Australian households [7]. To alleviate the impact caused by the energy crisis and climate change, the EU Parliament and Council have enacted several directives and rules which aim to reduce GHG emissions by $90 \%$ by 2050 [8]. In addition, the Australian government has ratified and signed the Kyoto Protocol, which commits to reducing GHG emissions by $60 \%$ by 2050 compared to 2000 levels [9].

The heat pump, a well-established and very efficient technology, is essential for reducing energy consumption and emissions, improving the energy efficiency of buildings, and contributing to the decarbonisation of the energy sector $[10,11]$. This is because a heat pump generates thermal output several times higher than the energy input and uses energy sources such as underground thermal mass or ambient air. In addition, heat pumps are now starting to use natural refrigerants, such as propane (R290), carbon dioxide (R744), and isobutane (R600a), in the heating and cooling sector [12,13]. Natural refrigerants have long been regarded as the optimal, environmentally friendly refrigerants and the best solutions to the problems of ozone depletion and global warming $[14,15]$ because they naturally exist in our environment and have low global warming potential (GWP) and no ozone depletion potential (ODP). The GWP measures the relative degree to which particular a gas in the atmosphere absorbs heat compared to an equivalent mass of carbon dioxide over a given amount of time. The ODP measures the ozone-depleting effect of a gas in comparison to an equivalent mass of R11 [16]. 
Another reason for adopting heat pumps is that they are one of the most promising technologies to use intermittent renewable energy sources. In Australia, rooftop solar photovoltaic (PV) systems are being installed rapidly in local households. Disparities between PV production, household energy demands, and low feed-in tariffs (FiTs) are major concerns of the owners of solar PV systems [17]. Increasing the self-consumption of $\mathrm{PV}$ electricity is becoming a priority for households. Self-consumption is the portion of the total PV production consumed by house loads [18]. Heat pumps can help to boost PV self-consumption by converting electrical energy to heat, rather than exporting it to the grid, and storing the surplus as thermal energy for later use [19], thereby helping to achieve Net Zero Energy Buildings (NZEBs). The utilization of environmentally friendly and energyefficient technologies, such as heat pumps, is one important element in achieving the decarbonisation of the energy sector and increasing the self-consumption of PV electricity.

Even though heat pumps have become the most commonly used technology in newly constructed dwellings in many countries, they only meet $5 \%$ of worldwide building heating demand at present [20]. In order to accomplish climate objectives, residential heat pumps will need to expand by more than tenfold from 20 million in 2015 to 253 million by 2050 [21]. Fortunately, policy makers are becoming aware of the potential of heat pumps to achieve a sustainable energy future. For example, to further reduce the use of fuel-based heat systems, the Chinese government implemented the policy of "coal-to-electricity" several years ago [22]. Under this policy, air-source heat pumps are selected and promoted, and residents who engage in the "coal-to-electricity" initiative receive financial support and preferential electricity prices from the government. Australian State Governments also provide incentives for switching from electric and other less-efficient water heaters to more efficient water heaters such as heat pumps or solar water heaters. For instance, Victorians can receive a 50\% rebate of up to AUD 1000 on solar or heat pump hot water systems under the Solar Homes Program [23]. So, the sales of heat pumps are expected to grow rapidly. However, the question is that, since there is a vast range of heat pumps, each with its advantages and disadvantages, which heat pump should be selected for residential buildings?

Therefore, this paper is a systematic literature review of all different heat pump systems applied in the residential sector and their roles in achieving the NZEBs target and decarbonizing the energy sector. We identify several heat sources and sinks that heat pumps can exploit. Heat pump applications are covered, such as heat pumps paired with thermal storage systems and heat pumps integrated with solar PV systems for cost savings and increased PV self-consumption. Environmental and economic aspects of heat pumps are also discussed. Finally, conclusions and suggestions are drawn.

\section{Method}

A comprehensive search of the literature from the last two decades was systematically reviewed to assist heat pump selection, application, and design for residential buildings. Google Scholar was the leading search engine used to find articles. The keyword "heat pump" was used to search, and articles were selected if the keyword appeared in the title. Figure 1 shows the number of publications grouped by year. It illustrates that approximately 1000 papers focusing on heat pumps have been published each year since 2008 .

The following criteria were used to limit the number of papers.

(1) Paper published only in the peer-reviewed journals or conferences,

(2) Papers published after 2001,

(3) Papers that evaluated the performance of heat pumps through simulations, or empirical analysis in residential buildings, and

(4) Papers that performed techno-economic analysis and comparisons on heat pumps under different climates.

The primary aim of this paper is to review the literature on heat pumps, the various types, and their design end uses. As such, papers that evaluated heat pump components and their applications were also selected. Moreover, articles citing the selected papers were 
assessed and kept if the content is highly relevant to the heat pump and its applications. In addition, some web pages with information related to heat pumps are also referenced in this paper. However, we only used government, research centre, or university websites and avoided using other online websites.

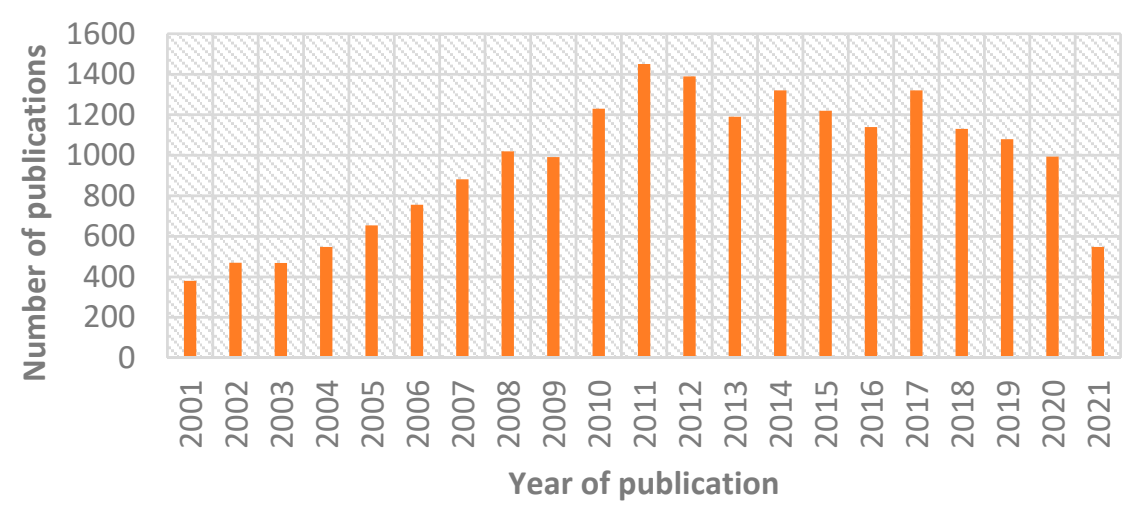

Figure 1. The number of publications with "heat pump" in the title.

\section{Heat Pump Basic Overview}

\subsection{Basic Refrigeration Cycle}

A heat pump is a device that absorbs heat energy on a low-temperature side, cooling that side, and transfers it to a high-temperature side, heating it [24]. The heat transfer is accomplished by circulating a refrigerant, compressed to heat it and expanded to cool it. As a liquid, the refrigerant evaporates in a low-temperature heat exchanger taking heat from the surroundings. The vapour is compressed and then condenses in a high-temperature heat exchanger releasing heat to its surroundings (see Figure 2).

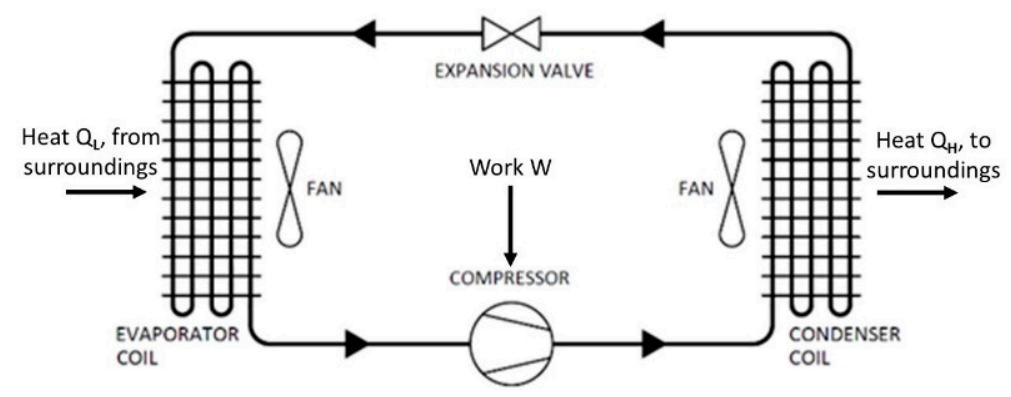

Figure 2. The schematic of a basic refrigeration cycle.

Four main components are included in heat pumps: compressor, expansion valve, and two heat exchangers (evaporator and condenser). Several other components may be used in heat pumps based on different designs. These are four-way valves, solenoid valves, flat plate heat exchangers, shell-in-tube heat exchangers, suction line heat exchangers, control valves, water pumps, electrical fans, auxiliary heaters, water pipes, and so on.

Heat pumps use two heat exchangers to exploit the property of heat to flow from a hotter to a cooler body. The refrigerant in one heat exchanger, the evaporator, is cooler than its surroundings and so absorbs heat from a source. The source is cooled. In the other, the condenser, the refrigerant is hotter and expels heat to a cooler sink.

Heat pumps rely on the fact that the environment of one heat exchanger is vastly and abundantly larger than that of the other. This large environment could be air, water, ground, solar energy, or even industrial waste heat. The other heat exchanger is in the environment to be heated or cooled. For example, in domestic hot water (DHW) systems, we may draw the heating energy from the air (the source) and deliver it to the sink (the hot water tank). The heat source and sink selection for a heat pump rely on several different aspects, such as location, climate, and source availability. 
The heat pump follows a four-stage cycle, compression, condensation, expansion, and evaporation. The refrigerant undergoes a phase change as it absorbs heat from the source. Later, reversing the phase change, the heat is transferred to the sink, such as air and water for space and hot water heating. Furthermore, by using a four-way valve to reverse the refrigerant flow, the heat pump can also absorb heat from an interior space and transfer it to the outside sink, making space cooling possible. The operating principles of the basic refrigeration cycle for space heating are explained as follows [8]:

(1) In the compression stage, the vapour state refrigerant is compressed, increasing its pressure and temperature.

(2) In the condensation stage, the high-temperature vapour refrigerant flows to the condenser, where the heat flows to the sink. The refrigerant becomes a liquid but is still at high pressure and temperature.

(3) The refrigerant pressure and temperature are reduced in the expansion stage as it flows into an expansion valve.

(4) In the evaporation stage, the cold liquid refrigerant is vaporized into a cold vapour refrigerant by absorbing heat from the source. The refrigerant flows into the compressor for the next cycle.

Work is done to compress the refrigerant. As energy is conserved, the heat absorbed on the low-temperature side augmented by the work equals the heat released on the high-temperature side:

$$
Q_{L}+W=Q_{H}
$$

where

$Q_{L}$ is the heat from the source;

$Q_{H}$ is the heat released to the sink;

$W$ is the work required.

Heat pumps are characterized by the Coefficient of Performance (COP), defined as the ratio of the heat flow of interest to the work required. For heating,

$$
C O P_{\text {heating }}=\frac{Q_{H}}{W}=\frac{Q_{L}+W}{W}
$$

and for cooling,

$$
C O P_{\text {cooling }}=\frac{Q_{L}}{W}
$$

For completeness, although less relevant to heat pumps, the Carnot, or ideal efficiency of a heat engine, is the ratio of the work done by the engine for a given heat input:

$$
\eta=\frac{W}{Q_{H}}=\frac{Q_{H}-Q_{L}}{Q_{H}}=1-\frac{Q_{L}}{Q_{H}}=1-\frac{T_{L}}{T_{H}}
$$

where

$T_{H}$ is the absolute temperature of the heat source of the engine; $T_{L}$ is the absolute temperature of the low temperature exhaust.

\subsection{Heat Pump Components}

Several other components can be applied to the heat pump based on different designs and improvements. This section introduces the details of a four-way valve, heat exchangers, including plate heat exchanger, shell-in-tube heat exchanger, and the suction line heat exchanger.

\subsubsection{Four-Way Valve}

A four-way valve is probably the component which distinguishes a heat pump from the conventional refrigeration cycle. It has been extensively used in the heat pump system design to obtain more than one operation mode because it can reverse the flow direction of the refrigerant in a heat pump. For example, in a basic heat pump, heat can be moved from 
the exterior space to the interior in space heating mode or removed from the interior space to the exterior in space cooling mode by using four-way valves.

\subsubsection{Heat Exchangers}

Heat exchangers are devices that transfer heat between two or more fluids at different temperatures. They are utilized in various applications, including refrigeration, heating, air conditioning systems, and so on. Thermal energy flows via three different methods, conduction, convection, and radiation. Convection is used to transfer thermal energy in the evaporator and condenser coils of the basic heat pump refrigeration cycle. Flat plate heat exchangers and shell-in-tube heat exchangers are two common heat exchangers that transfer heat via conduction. The flat plate heat exchanger is composed of a set of connected plates (see Figure 3), and each flat plate contains four inlet and outlet ports and seals that route the fluid through alternate flow paths. The flow tunnels are formed by adjacent flat plates, allowing the two fluids to exchange heat while passing through alternate channels and never mixing [25].
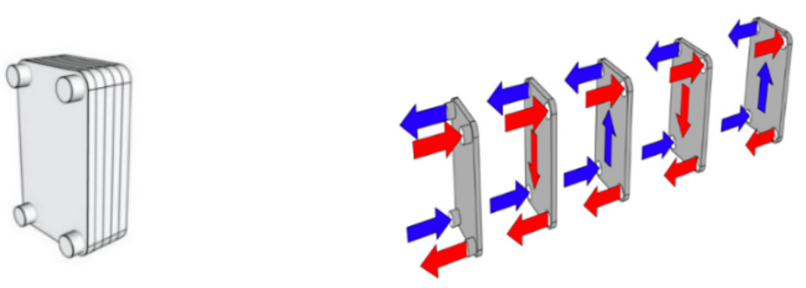

Figure 3. The schematic of the flat plate heat exchanger.

A shell-in-tube heat exchanger is made up of a series of tubes placed inside a shell (see Figure 4). There are two inlets and two outlets, where two fluids can start at their respective inlet and exit the heat exchanger at their outlets. One fluid flows through the tubes, while the other flows outside the tubes but within the shell. Then, the heat is transmitted between two fluids via tube walls. The baffles within the heat exchanger aim to prevent the fluid's back flow and ensure that the fluid can contact all the tubes within the shell, thus maximizing heat transfer efficiency [26]. It is claimed that the shell-in-tube heat exchanger has a higher COP than the flat plate heat exchanger used in the condenser side of heat pump systems.

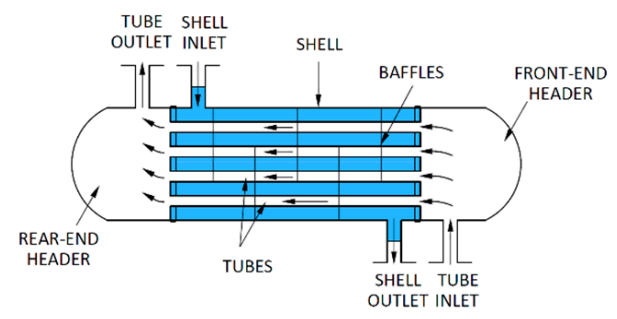

Figure 4. The schematic of shell-in-tube heat exchanger [27].

\subsubsection{Suction Line Heat Exchanger}

A suction-line heat exchanger, also called an internal heat exchanger, can be used in the refrigeration cycle (see Figure 5). It is designed for the gas refrigerant exiting the evaporator to absorb heat from the liquid refrigerant leaving the condenser. Furthermore, a suction line heat exchanger prevents the liquid refrigerant from entering the compressor by boiling off any excess liquid in the suction line, improving the system performance [28]. A study of the suction line heat exchanger and R290 on room air conditioning (RAC) performance showed that the suction line heat exchanger could increase energy savings and the COP by up to around $28 \%$ and $38 \%$, respectively, compared to the standard RAC system with R22 as the refrigerant [29]. 


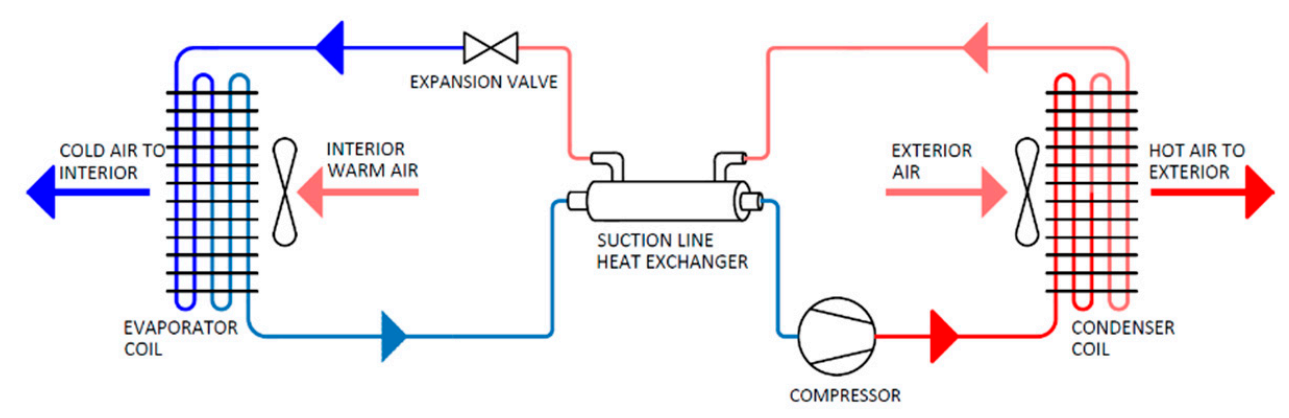

Figure 5. The schematic of a basic heat pump refrigeration cycle with a suction line heat exchanger.

\section{Classification of Heat Pumps}

Heat pumps may be classified by several different features, such as the types of heat sources and sinks, their functions, applications, and types of energy used. The types of sources and sinks used by heat pumps include water, air, ground, solar energy, or even industrial waste heat. Heat pumps can provide three main functions: space heating and cooling, and hot water heating in the residential and commercial sectors. In addition, they can be used in the industrial sector for drying, food preparation or paper manufacturing, amongst other uses. Electrical, mechanical, and thermal energy are the three main energy categories employed to drive heat pumps based on different design configurations.

The following sections describe the most common heat pumps in residential buildings: air source heat pump, water source heat pump, ground source heat pump, solar-assisted heat pump, cascade heat pump, and two-stage heat pump. These heat pumps are electrically driven devices that can provide space heating, space cooling, and DHW heating purposes for residential buildings. Thermally driven heat pumps are also used in the commercial sector.

\subsection{Air Source Heat Pump (ASHP)}

For air source heat pumps, air is the fundamental heat source. Air source heat pumps consist of air-to-air or air-to-water heat pumps. They have been widely used for heating, cooling, and DHW heating because of their simple operation, high system performance, and good environmental characteristics [30]. ASHPs can replace fossil fuel boilers directly, thereby decarbonizing the residential sector's space and water heating needs. A study in the UK showed that an ASHP used for underfloor heating could save up to $37 \%$ of costs and GHG emissions compared with a conventional boiler system [31]. Furthermore, ASHPs have been considered the best option for China's national "coal to electricity" policy because of their energy savings and environmental friendliness [22].

\subsubsection{Air-to-Air Heat Pump}

The air-to-air heat pump is the most common system used in residential and commercial applications (see Figure 2). In this system, one heat exchanger coil works as the evaporator to extract heat from the ambient air, and the other works as the condenser to dissipate heat to the ambient air. It is important to note that the evaporator coil will be used for cooling in the summer, and the condenser coil for heating in the winter. A study was conducted to investigate the performance of an air-to-air heat pump, for space heating in Harbin, with an extremely cold climate [30]. The results indicated air-to-air heat pumps could be applied for heating purposes, but for an acceptable COP, the temperature difference between indoor and outdoor air must be kept within $41{ }^{\circ} \mathrm{C}$. Climatic conditions can significantly impact the performance of air-to-air heat pumps. An investigation was conducted to analyse the impact of climate on the seasonal coefficient of performance (SCOP) of air-to-air heat pumps [32]. The results indicated that the difference in SCOP of air-to-air heat pumps between Poland's average and cold climates was approximately $36 \%$. 


\subsubsection{Air-to-Water Heat Pump}

Air-to-water heat pumps commonly called heat pump water heaters (see Figure 6), are used in the residential sector to produce hot water. Ambient air works as a heat source in this system, and water acts as a heat sink. Air-to-water heat pumps have been highly regarded for residential heating and occupy a growing share in the European heating market [33]. A techno-economic feasibility study of an air-to-water heat pump retrofit for space and hot water heating was carried out in Canadian housing stock [34]. The study found a maximum $36 \%$ reduction in energy use and a $23 \%$ decrease in GHG emissions of base cases that normally consumed large amounts of fossil fuels for heating purposes. The performance of an air-to-air heat pump and an air-to-water heat pump for space heating was compared in the cold regions of China [22]. The results indicated that air-to-air heat pumps have a greater heating capacity than air-to-water heat pumps in low-temperature conditions. This may be because the limited thermal capacity of water tanks restricts the operation time of the air-to-water heat pump, and a higher condensation temperature of the air-to-water reduced its $\mathrm{COP}$ compared to the air-to-air heat pump at low-temperature conditions.

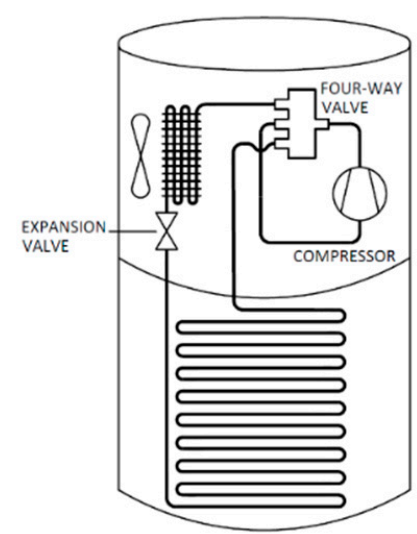

Figure 6. The schematic of the air-to-water heat pump as a DHW system.

The effectiveness of ASHPs decreases as the ambient temperature drops in cold conditions. This is because less heat energy can be absorbed by the evaporator from the ambient air when the ambient temperature is low in winter [35]. In addition, frost formation is another major concern in selecting an ASHP. During the heating season, when the surface temperature of the evaporator coil is below $0{ }^{\circ} \mathrm{C}$, frost forms regularly. Frosting on the evaporator coil obstructs airflow and functions as a heat barrier, leading to a significant reduction in system performance [36]. Furthermore, frost can cause the liquid refrigerant to flood back into the compressor, causing space heating to fail. To achieve a better system performance, many studies have focused on the defrost mode of ASHPs. Main strategies include: (1) using an external heat source to heat the evaporator coil, (2) reversing the refrigeration cycle by using the four-way valve, or (3) adding the Dual Hot-Gas Bypass Defrosting to the outlet of the compressor [36,37]. Table 1 presents the summary of studies of ASHPs. 
Table 1. Summary of studies of ASHP systems.

\begin{tabular}{|c|c|c|}
\hline References & System Designs & Performance \\
\hline$[30]$ & $\begin{array}{l}\text { Air-to-air heat pump } \\
\text { Load: space heating } \\
\text { Region: Harbin, China }\end{array}$ & $\begin{array}{l}\text { COP: ranging from } 1.04 \text { to } 2.44 \text { with extremely cold } \\
\text { climates (ambient temperatures of }-20.9^{\circ} \mathrm{C} \text { to } 10.4^{\circ} \mathrm{C} \text { ) } \\
\text { Frost formation: little frost formation on the outdoor } \\
\text { evaporator due to low relative humidity }\end{array}$ \\
\hline [32] & $\begin{array}{l}\text { Air-to-water heat pump } \\
\text { Load: space heating } \\
\text { and DHW } \\
\text { Region: the UK }\end{array}$ & $\begin{array}{l}\text { The cost and GHG emission of an } 8.5 \mathrm{~kW} \text { heat pump } \\
\text { with a } 300 \mathrm{~L} \text { thermal energy storage system operating on } \\
\text { E10 electricity tariff are } 37 \% \text { less than a gas boiler system. }\end{array}$ \\
\hline [34] & $\begin{array}{l}\text { Air-to-water heat pump } \\
\text { Load: space heating } \\
\text { and DHW } \\
\text { Region: the Canada }\end{array}$ & $\begin{array}{l}\text { COP: ranging from } 3.2 \text { to } 3.6 \\
\text { Approximately } 36 \% \text { of energy use and } 23 \% \text { of GHG } \\
\text { emissions can be reduced by adopting air-to-water heat } \\
\text { pumps in the Canadian housing stock. }\end{array}$ \\
\hline$[35]$ & $\begin{array}{l}\text { Air-to-water heat pump } \\
\text { Load: space heating } \\
\text { Region: the northern } \\
\text { region in China }\end{array}$ & $\begin{array}{c}\text { COP: } 3.1 \text { in heating season } \\
\text { Primary energy consumption: } 68 \% \text { less than direct } \\
\text { electric heating, } 48 \% \text { less than regional coal-fired } \\
\text { boiler heating } \\
\text { Initial costs: ASHPs have the lowest initial costs } \\
\text { compared to other devices after considering both } \\
\text { heating and cooling. } \\
\text { Running costs: } 60 \% \text { less that direct electric heating }\end{array}$ \\
\hline [36] & $\begin{array}{l}\text { Air-to-air heat pump } \\
\text { Load: space heating } \\
\text { Region: Not specified }\end{array}$ & $\begin{array}{l}\text { COP: ranging from } 1.5 \text { to } 3.0 \\
\text { At the ambient temperature of } 2{ }^{\circ} \mathrm{C} \text {, using a } 1 \mathrm{~kW} \\
\text { electric heater heating evaporator coil can increase the } \\
\text { heating capacity and the COP by } 38 \% \text { and } 57 \% \text { and } \\
\text { reduce the power consumption by } 11.7 \% \text { than the } \\
\text { conventional air-to-air heat pump. }\end{array}$ \\
\hline
\end{tabular}

\subsection{Water Source Heat Pump (WSHP)}

Water can be a good heat source and sink in heat pumps because water has a significantly higher density and approximately four times greater specific heat capacity than air. It can contain considerably more energy per volume than air. Therefore, water also has a smaller temperature range than air. Water source heat pumps include water-to-air and water-to-water heat pumps.

\subsubsection{Water-to-Water Heat Pump}

Water works as both the heat source and sink in water-to-water heat pumps for heating or cooling (see Figure 7). Again, because the water has better heat transfer and thermal properties, the COP of heat pumps using water as a heat source can be greater than using air because the refrigerant can absorb more heat in the evaporator side of heat pumps. An experimental multifunctional heat pump system was proposed to investigate the performance variation of four different heat pumps using air and water as the heat source and sink for heating purposes [38]. The results showed that water to air and water to water heat pumps yield the two highest COP of 3.94 and 3.73 greater than 3.54 and 3.4 of an air-to-air heat pump and air-to-water heat pump. Water-to-water heat pumps can also be integrated into domestic water networks for heating purposes. Greater control, centrally managed maintenance, redundancy, and adaptability are advantages of this system [39]; disadvantages may include the risk of water contamination and high investment costs. 


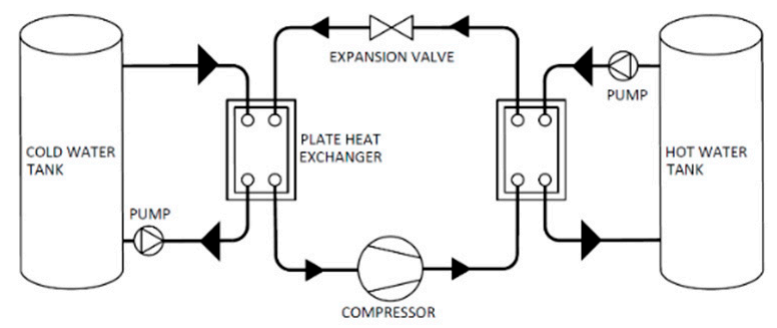

Figure 7. The schematic of the water-to-water heat pump.

\subsubsection{Water-to-Air Heat Pump}

Water-to-air heat pumps use water as a heat source or sink and employ air to transfer the heat for heating or cooling. Water can be groundwater extracted from wells or surface water extracted from ponds, lakes, or rivers. Buildings close to these surface water bodies can take advantage of the benefits of exploiting these water sources. Groundwater is particularly appealing as a heat source or sink due to its year-round constant temperature [39]. In the groundwater heat pump (see Figure 8), water is generally drawn from one well and injected into another well.

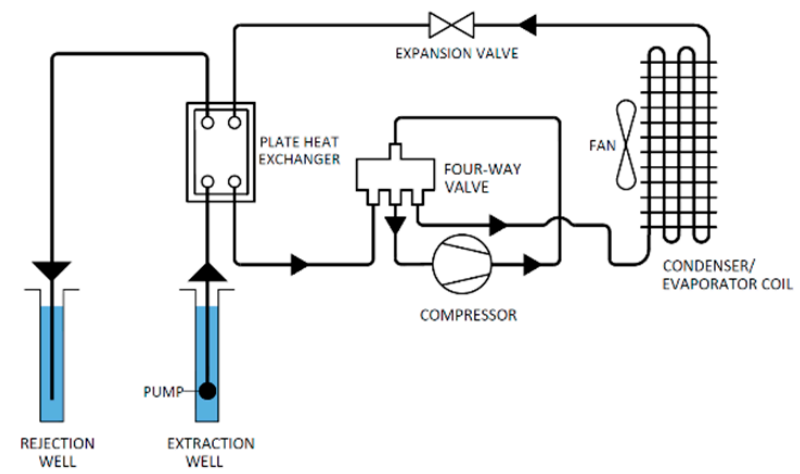

Figure 8. The schematic of the groundwater heat pump in heating mode.

Surface water heat pumps (SWHPs) are classified into two types: open-loop and closed-loop. In the open-loop system (see Figure 9a), Water from the river or lake is pumped through the heat exchanger of heat pumps and returned to the rivers or lakes at a distance. In the closed-loop system (see Figure 9b), a heat exchange coil is typically installed in the surface water body instead of directly pumping surface water to the heat pump. Therefore, the antifreeze solution in the coil can exchange the heat with surface water before entering the heat pump. Then, the heat pump absorbs or releases heat from/to the air in the conditioned space.
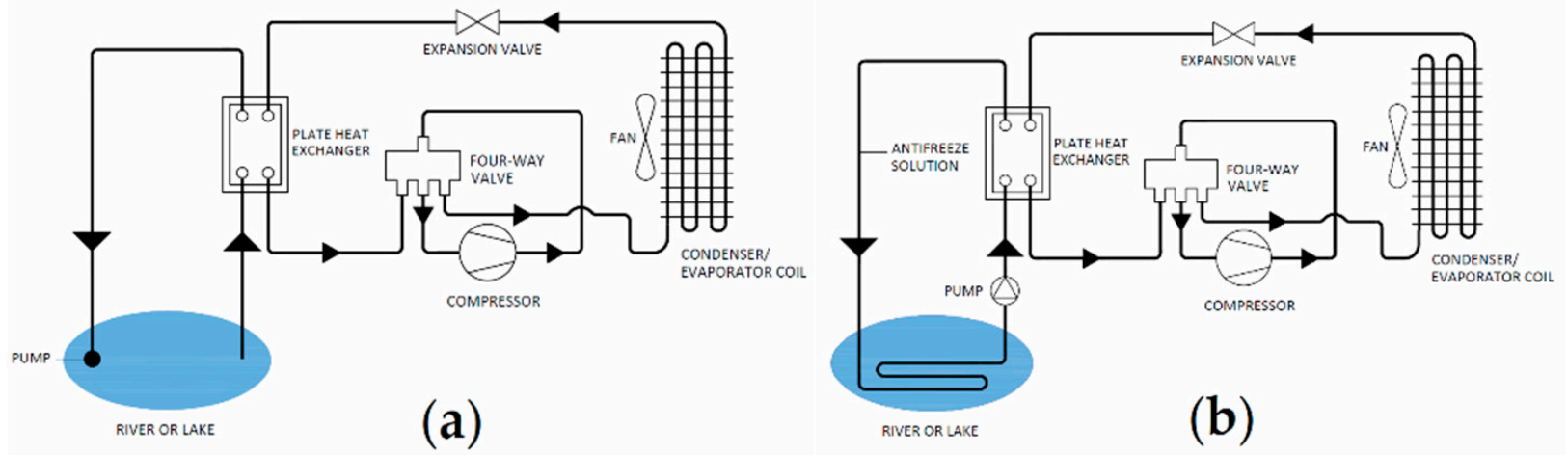

Figure 9. The schematic of (a) the open-loop SWHP and (b) the closed-loop SWHP in heating mode. 
The relatively low initial cost due to the reduced excavation cost and low operation cost can be two main advantages for closed-loop surface water heat pumps [39]. Significant water temperature variation under different climates can be a disadvantage for both open and closed systems [40]. On the other hand, water quality must be considered for both open-loop SWHPs and groundwater heat pumps because the heat exchanger between the refrigerant and ground/surface water can become fouled, corroded, or blocked.

Several studies have investigated the COP or energy performance of WSHPs. For example, An open-loop SWHP system used for a historical centre in Venice was monitored and compared with an ASHP system, an air-cooled chiller, and a boilers system [41]. The results suggested that this WSHP system saved about $37 \%$ of energy consumption compared to conventional systems. Accordingly, WSHPs generally have a higher COP than ASHPs, because water has better heat transfer and thermal properties. An open-loop lake water heat pump used for district heating and cooling was examined and compared with an ASHP at the same heat source and sink temperatures [42]. The results indicated that this heat pump could satisfy buildings' heating and cooling demands, but auxiliary heating devices were required on several cold days. Table 2 present the summary of studies of WSHPs.

Table 2. Summary of studies of WSHP systems.

\begin{tabular}{|c|c|c|}
\hline References & System Designs & Performance \\
\hline [38] & $\begin{array}{l}\text { Water to-air, Water-to-water, } \\
\text { Air-to-water, Air-to-air } \\
\text { heat pump } \\
\text { Load: heating, cooling } \\
\text { and DHW, } \\
\text { Region: Turkey }\end{array}$ & $\begin{array}{c}\text { COP: } 3.94 \text { for water-to-air, } 3.73 \text { for } \\
\text { water-to-water, } 3.54 \text { for air-to-air, } 3.40 \text { for } \\
\text { air-to-water }\end{array}$ \\
\hline [41] & $\begin{array}{l}\text { Open-loop SWHP } \\
\text { Load: space heating, space } \\
\text { cooling and DHW } \\
\text { Region: Venice, Italy }\end{array}$ & $\begin{array}{l}\text { COP: The average COP of the SWHP is } 3.66 \text {, } \\
\text { which is } 36 \% \text { higher than ASHP in the } \\
\text { heating season. } \\
\text { Energy efficiency ratio (EER): The average EER } \\
\text { of the SWHP is } 4.13 \text {, which is } 14 \% \text { higher than } \\
\text { ASHP in the cooling season. } \\
\text { Primary energy consumption: } 37 \% \text { of annual } \\
\text { energy savings can be achieved by SWHP } \\
\text { compared to traditional systems. }\end{array}$ \\
\hline [42] & $\begin{array}{l}\text { Open-loop Lake water } \\
\text { heat pump } \\
\text { Load: district heating } \\
\text { and cooling } \\
\text { Region: Xiangtan, China }\end{array}$ & $\begin{array}{l}\text { COP: } 0.7-0.85 \text { higher COP in cooling mode and } \\
\text { around } 0.46 \text { higher in the heating season than } \\
\text { the ASHP system } \\
\text { Payback period: } 5.6 \text { years is obtained for this } \\
\text { heat pump compared to the ASHP units. }\end{array}$ \\
\hline
\end{tabular}

\subsection{Ground Source Heat Pump (GSHP)}

The ground is widely used as a heat source and sink in heat pumps for space heating and cooling due to its relatively stable temperature compared to the ambient air temperature [43]. The ground has been considered as one of the world's most efficient renewable energy sources as it is environmentally friendly, long-lasting, appropriate for storage, and available throughout the day [44]. The ground-coupled heat pump (GCHP), the direct expansion ground source heat pump (DX-GSHP), and the groundwater heat pump, discussed above, are the three types of ground source heat pumps.

\subsubsection{Ground Coupled Heat Pump (GCHP)}

The ground is used as a heat source or sink in a GCHP system. The ground heat exchanger (GHE) and a refrigerant-to-water heat exchanger are used in GCHP systems. As the secondary working fluid, water and antifreeze solutions are pumped through the GHE, exchanging heat with the surrounding soil or rock and then flowing back to the 
refrigerant-to-water heat exchanger in the heat pump system [45]. The GHE can be placed in a horizontal trench around one to two meters deep for horizontal GCHPs (see Figure 10a). Consequently, a significant amount of land area is required, which can be a problem for some cases with insufficient land. Moreover, because of the shallow burial depth, the heat exchange rate between solutions and the surrounding soil or rock is sensitive to seasonal variations [46]. The low installation costs and ease of maintenance are two advantages of horizontal GCHPs compared to vertical GCHPs [47].

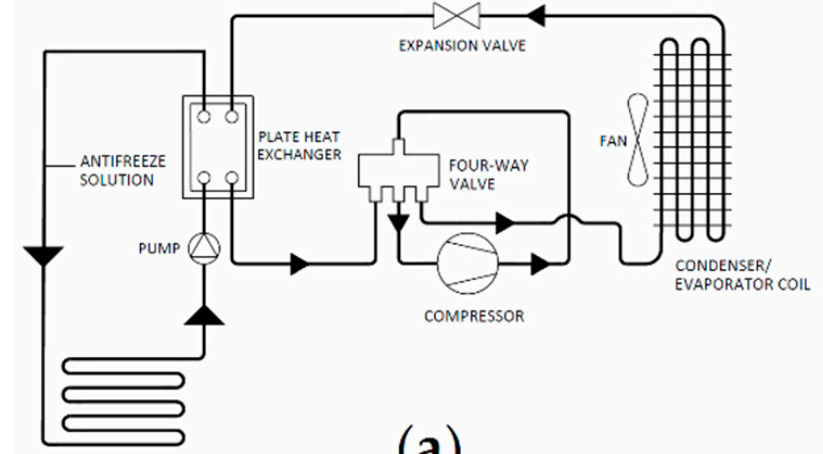

(a)

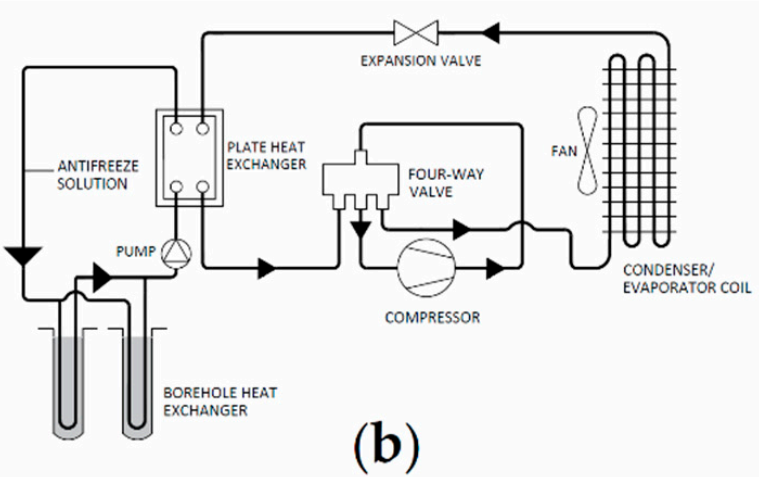

(b)

Figure 10. The schematic of the GCHP (a) with horizontal heat exchangers and (b) with vertical heat exchangers in heating mode.

Alternatively, GHEs can also be placed vertically in boreholes at a depth of around 50 to $150 \mathrm{~m}$ for GCHPs (see Figure 10b). Vertical GCHPs are more feasible than horizontal in high-density housing areas because the land area needed is much less [48]. High installation costs from borehole drilling can be the main obstacle for vertical GCHPs [49]. However, because the ground lower than ten meters has a relatively constant temperature throughout the year, vertical GCHPs can yield a higher system performance than horizontal GCHPs [50].

Many studies have been conducted to investigate the effectiveness of GCHPs, examining the COPs of GCHP systems with horizontal GHEs and vertical GHEs for greenhouse heating in a mild climate zone. The results indicated that the GCHP system with vertical GHEs yielded a higher COP than horizontal GHEs, but at a significantly increased cost due to drilling boreholes, which can be a disadvantage for installing vertical GHEs. To better improve the COP of horizontal GCHPs, an evaluation of the performance of GCHPs with horizontal GHEs configurations in a hot climate zone illustrated that increasing the length of GHEs can increase the heat exchange rate and the COP of systems, but its increase is not linear [51].

\subsubsection{Direct Expansion-Ground Source Heat Pump (DX-GSHP)}

In the DX-GSHP system, the refrigerant is directly pumped through the borehole heat exchanger and exchanges heat with the surrounding soil (see Figure 11). That means borehole heat exchangers work as an evaporator in the space heating mode or as a condenser in the space cooling mode. DX-GSHP systems have the advantages of lower initial costs and higher system performance than conventional vertical GCHPs.

A DX-GSHP was compared with a vertical GCHP system for the same space cooling in a residential building located in Changsha, China, with a moist sub-tropical monsoon climate [52]. The results showed that the DX-GSHP system has higher efficiency and lower cost compared with conventional heating and cooling systems, and its COP was over 6 , higher than 5.6 of the GCHP system.

On the other hand, DX-GSHPs have significant drawbacks, such as large refrigerant requirements, potential leaks of refrigerant and metal corrosion. It is suggested that the metal used for refrigerant piping must be resistant to both the refrigerant and the grouting, which is used in the borehole heat exchanger and surrounds the piping [53]. 


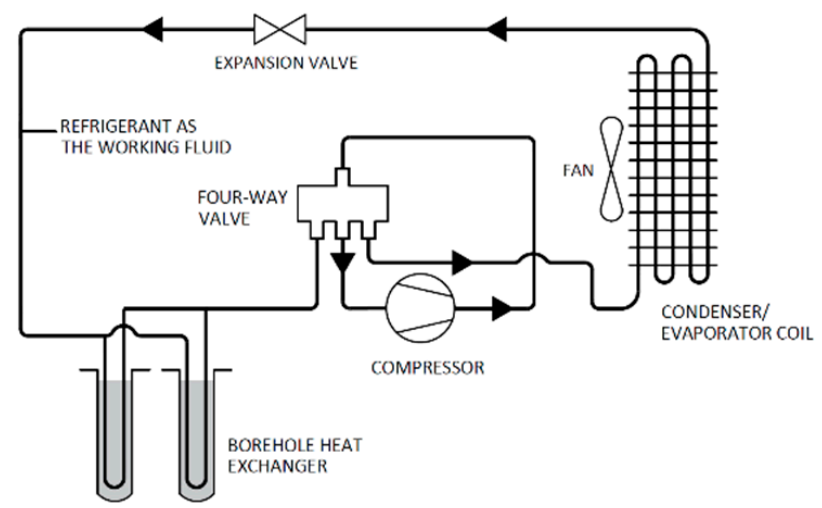

Figure 11. The schematic of the DX-GSHP system in heating mode.

GSHPs can perform better than ASHPs in extreme conditions because the ground has a more constant temperature throughout the year [54], Furthermore, soil composition can significantly impact the thermal properties and productivity of GSHPs because it determines the heat transfer rate. For better heat transfer rate of horizontal GSHPs, the separation between pipes is critical and must be sufficient to avoid thermal interference between parallel pipes [55]. Long-term ground temperature changes caused by heat accumulation or depletion can degrade the efficiency of GSHPs [56]. Especially in areas where only heating or cooling is required, ensuring that the amount of heat being extracted or injected is not higher than the natural regeneration [57]. Another solution is that the GSHPs should be operated on an intermittent basis, so the accumulated heat can spread into the earth periodically. The performance of GSHPs with different heat recovery ratios was simulated and compared to that of the conventional GSHPs during a long period [58]. The results found that, in hot-summer and cold-winter regions, GSHPs with high heat recovery ratios can alleviate ground thermal imbalance caused by long time operation, meaning that GSHPs with heat recovery can be a promising approach for buildings in regions with hot or cold climates. Table 3 presents the summary of studies of GSHPs.

Table 3. Summary of studies of GSHP systems.

\begin{tabular}{|c|c|c|}
\hline References & System Designs & Performance \\
\hline [44] & $\begin{array}{l}\text { Vertical GCHP } \\
\text { Load: space heating and } \\
\text { space cooling } \\
\text { Region: Tabriz, Iran }\end{array}$ & $\begin{array}{l}\text { Suggestions: The distance between spiral GHEs } \\
\text { needs to be at least } 6 \mathrm{~m} \text { for the system } \\
\text { performance loss less than } 20 \% \text {. } \\
\text { The length of spiral GHEs and the buried depth } \\
\text { from ground surface should be at least } 4 \mathrm{~m} \text { and } \\
2 \mathrm{~m} \text {, respectively, for better system performance. }\end{array}$ \\
\hline [45] & $\begin{array}{l}\text { Vertical and horizontal } \\
\text { GCHPs } \\
\text { Load: space heating } \\
\text { Region: Iowa, U.S. }\end{array}$ & $\begin{array}{l}\text { Average COP: horizontal one ranging from } 1.81 \\
\text { to } 3.71 \text {, the vertical one ranging from } 1.96 \text { to } 3.80 \text {. } \\
\text { Costs: median savings of } 70-7 \% \text { in fuel cost for } \\
\text { GCHPs compared to natural gas furnaces } \\
\text { GHG emissions: } 45 \% \text { less emission for GCHPs } \\
\text { than natural gas furnaces. }\end{array}$ \\
\hline [47] & $\begin{array}{c}\text { Vertical GCHP } \\
\text { Load: space heating and space } \\
\text { cooling } \\
\text { Region: Valencia, Spain }\end{array}$ & $\begin{array}{l}\text { Energy consumption: an average of } 26-60 \% \text { of } \\
\text { energy savings in the heating season and } 19 \text { to } \\
45 \% \text { of energy savings in the cooling season than } \\
\text { the conventional air-to-water heat pump. }\end{array}$ \\
\hline [53] & $\begin{array}{l}\text { Vertical and horizontal } \\
\text { GCHPs } \\
\text { Load: space heating } \\
\text { Region: Elaziğ, Turkey }\end{array}$ & $\begin{array}{c}\text { COP: } 3.1-3.6 \text { for horizontal GCHP, 3.2-3.8 for } \\
\text { vertical GCHP } \\
\text { The vertical GCHP is more efficient than the } \\
\text { horizontal one, but its installation cost is higher. }\end{array}$ \\
\hline
\end{tabular}


Table 3. Cont.

\begin{tabular}{|c|c|c|}
\hline References & System Designs & Performance \\
\hline [51] & $\begin{array}{c}\text { Horizontal GCHP } \\
\text { Load: space cooling } \\
\text { Borj Cédria, northern Tunisia }\end{array}$ & $\begin{array}{l}\text { COP: The COP of GCHP ranges from } 3.8 \text { to } 4.5 \text {, } \\
\text { and the COP of the overall cooling system } \\
\text { ranges from } 2.3 \text { to } 2.7 \text {. } \\
\text { The exergy efficiency of GHE decreases from } 36 \% \\
\text { to } 12 \% \text {, with the mass flow rate of circulating } \\
\text { water increasing from } 0.06 \text { to } 0.20 \mathrm{~kg} / \mathrm{s} \text {. }\end{array}$ \\
\hline$[52]$ & $\begin{array}{l}\text { DX-GSHP and vertical GCHP } \\
\text { Load: space heating } \\
\text { and cooling } \\
\text { Region: Changsha, China }\end{array}$ & $\begin{array}{c}\text { Average COP: } 6.03 \text { for DX-GSHP, } 5.64 \text { for } \\
\text { vertical GCHP } \\
\text { Average power consumption: } 1.39 \mathrm{kWh} \text { for } \\
\text { DX-GSHP and } 1.715 \mathrm{kWh} \text { for vertical GSHP } \\
\text { Initial cost: The vertical GCHP is } 1000 \text { yuan less } \\
\text { than the DX-GSHP system, but the DX-GSHP } \\
\text { has the lower annual cost with a payback period } \\
\text { of } 2.13 \text { years against the GCHP. }\end{array}$ \\
\hline$[54]$ & $\begin{array}{c}\text { Vertical GCHP } \\
\text { Load: space heating } \\
\text { and cooling } \\
\text { Region: Saudi Arabia }\end{array}$ & $\begin{array}{c}\text { COP: } 4.4 \text { for the GCHP and } 2.3 \text { for the } \\
\text { conventional ASHP } \\
\text { Cost: } 34.6 \% \text { of the annual cost savings on power } \\
\text { consumption than the ASHP } \\
\text { Payback period: } 15.6 \text { years compared to } \\
\text { the ASHP }\end{array}$ \\
\hline [55] & $\begin{array}{l}\text { Horizontal GCHP } \\
\text { Load: space heating } \\
\text { and cooling } \\
\text { Region: Karaj, Iran }\end{array}$ & COP: 2.7 for the heating COP \\
\hline
\end{tabular}

\subsection{Solar Assisted Heat Pump (SAHP)}

In the field of renewable energy, solar energy is regarded as an optimum energy source. It can be used as a sole heat source for heat pumps or in conjunction with other sources such as air and ground. Due to different connection approaches of the solar collector and evaporator, SAHP can be classified as a direct expansion-solar assisted heat pump (DX-SAHP) and indirect expansion solar-assisted heat pump (IX-SAHP) system. Because the solar assisted ground source heat pump is not very cost-effective or appealing [59], only the solar assisted air source heat pump is considered in this paper.

\subsubsection{Direct Expansion-Solar Assisted Heat Pump (DX-SAHP)}

The DX-SAHP was first introduced in 1955 as a low-temperature solar thermal conversion technology. A DX-SAHP is formed when the refrigerant is pumped through the solar collector directly and absorbs heat from the solar energy, implying that the solar collector serves as an evaporator (see Figure 12).

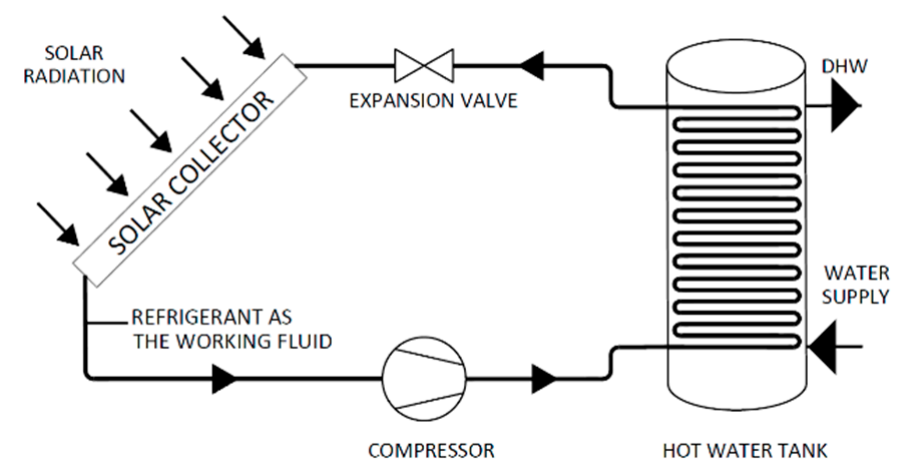

Figure 12. The schematic of the DX-SAHP system. 
The solar collector in the DX-SAHP system is usually a flat plate type without any back insulation so that heat can also be extracted from the ambient air using the solar collector [60]. The water in the hot water tank works as a heat sink that absorbs heat from the refrigerant. Consequently, hot water can be produced. The main advantage of DX-SAHP is that a higher temperature heat can be delivered to heat pumps, and heat losses can be avoided from the secondary heat exchange due to the refrigerant flowing directly from the solar thermal collector to the compressor [61]. An investigation of the system efficiency of a DX-SAHP in the fall and winter showed that, on sunny and cloudy autumn days, the mean COP was greater than 4 and 3, respectively, and the mean COP in the most severe winter weather conditions was greater than 2.5 [62]. Solar intermittency, on the other hand, may harm heat pump system performance. Integrating solar energy with other sources, such as air or ground, can be a viable solution for this problem.

Another advantage is that the DX-SAHP is more practical under frosting conditions. The frosting features of a DX-SAHP space heating system was experimentally tested [63]. The results showed that the frost formation on the solar collector was slower than the heat pump with fin-and-tube heat exchanger, indicating that DX-SAHP is more practical in freezing conditions. On the other hand, owing to the extensive refrigerant circulation loop, refrigerant leakage and refrigerant blockage in the evaporator and condenser may occur [64].

\subsubsection{Indirect Expansion-Solar Assisted Heat Pump (IX-SAHP)}

IX-SAHP systems are currently one of the most popular designs for SAHP systems due to their simple hydraulic systems, ease of maintenance, well-developed technology, and highly reliable performance [65]. IX-SAHP has three design configurations depending on multiple connection concepts between the solar thermal collector and the heat pump: series, parallel, and dual-source. For example, in the series configuration (see Figure 13), the antifreeze solution is pumped through the solar collector and absorbs heat from solar radiation. Then, heat is stored in the thermal storage tank and later transferred to the heat pump via a plate heat exchanger (heat pump evaporator).

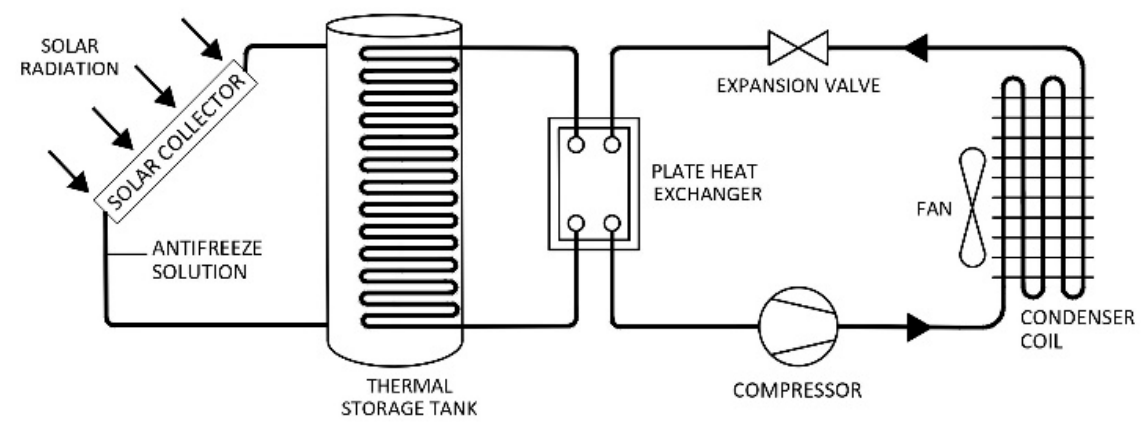

Figure 13. The schematic of the series IX-SAHP system.

The solar thermal collector and heat pump work independently to provide heating in the parallel system design. This can ensure continuous heat supply even if one of the two elements breaks down. Solar collectors alone can meet the heating load when there is enough solar radiation. Heat pumps are used when more heating is needed, or there is not enough solar radiation. Both solar energy and ambient air serve as heat sources for the heat pump in the dual-source system. To achieve a higher COP, the heat pump uses the highest temperature source, either the thermal storage tank heated by solar radiation or ambient air $[66,67]$. A greater capital cost and more complex control system may be required to better drive the dual-source IX-SAHP, given the extensive configuration and the matching relationship between components [61].

Numerous scholars have carried out studies investigating the performance of IX-SAHP. A novel IX-SAHP with four heat exchangers was designed and used for space heating, cooling, and DHW heating [68]. The authors found that this novel IX-SAHP is particularly 
well suited to places with sufficient solar radiation, where space heating, cooling, and hot water heating are needed throughout the year. A verified theoretical model for a parallel IX-SAHP system was designed and tested in $[69,70]$. The results found that the COP of 2.34 and $70 \%$ of energy savings could be obtained by this IX-SAHP than conventional solar hot water system combined with electrical resistance or a direct-fired heater. Moreover, a novel dual-source IX-SAHP system was developed and integrated with a phase change material (PCM) storage tank for storing excess energy during the daytime [71]. The authors discovered that installing a PCM storage tank can significantly affect the system stability and improve the COP of the IX-SAHP system under different climates with a defined hot water load profile. Table 4 summarizes the studies of SAHPs.

Table 4. Summary of studies of SAHP systems.

\begin{tabular}{|c|c|c|}
\hline References & System Designs & Performance \\
\hline [61] & $\begin{array}{l}\text { Parallel and series IX-SAHPs } \\
\text { Load: DHW } \\
\text { Region: Xi'an, China }\end{array}$ & $\begin{array}{l}\text { COP: } 4.34 \text { for the parallel system and } 3.23 \text { for the } \\
\text { series system } \\
\text { Annual energy consumption: } 894 \text { GJ for the } \\
\text { parallel system and } 1200 \text { GJ for the serial system }\end{array}$ \\
\hline$[62]$ & $\begin{array}{c}\text { DX-SAHP } \\
\text { Load: DHW } \\
\text { Region: Qingdao, China }\end{array}$ & $\begin{array}{l}\text { COP: ranging from } 2.55 \text { to } 6.57 \text {, with the average } \\
\text { value higher than } 4.0 \text { and } 3.0 \text { on sunny and } \\
\text { overcast days of autumn. }\end{array}$ \\
\hline [63] & $\begin{array}{c}\text { DX-SAHP } \\
\text { Load: space heating } \\
\text { Region: Hefei, China }\end{array}$ & $\begin{array}{l}\text { COP: ranging from } 1.50 \text { to } 2.23 \text { with different } \\
\text { levels of solar irradiation, ambient temperature, } \\
\text { and relative humidity } \\
\text { Frost formation: Frost forming on the collector of } \\
\text { DX-SAHP is slower than heat pumps with the } \\
\text { fin-and-tube heat exchanger. }\end{array}$ \\
\hline [64] & $\begin{array}{l}\text { DX-SAHP } \\
\text { Load: space heating, space } \\
\text { cooling and DHW } \\
\text { Region: Shanghai, China }\end{array}$ & $\begin{array}{c}\text { System COP: ranging from } 2.1 \text { to } 2.7 \text { in the } \\
\text { heating mode, } 2.1 \text { to } 3.5 \text { in the water heating } \\
\text { mode, and } 2.9 \text { for average system COP in } \\
\text { cooling mode } \\
\text { Costs: relatively low running costs during the } \\
\text { entire year }\end{array}$ \\
\hline$[69,70]$ & $\begin{array}{l}\text { Parallel IX-SAHP } \\
\text { Load: DHW } \\
\text { Region: Athens, Greece }\end{array}$ & $\begin{array}{c}\text { COP: } 2.34 \\
\text { Energy consumption: } 70 \% \text { energy savings } \\
\text { compared to conventional solar hot water } \\
\text { system combined with electrical resistance or a } \\
\text { direct-fired heater }\end{array}$ \\
\hline$[71]$ & $\begin{array}{l}\text { Novel IX-SAHP } \\
\text { Load: DHW } \\
\text { Region: the UK }\end{array}$ & $\begin{array}{l}\text { COP: maximum COP of } 4.99 \text { and } 4.80 \text { for the } \\
\text { sunny day and cloudy day with PCM tank, } \\
\text { maximum COP of } 4.70 \text { and } 4.21 \text { for the sunny } \\
\text { day and cloudy day without PCM tank }\end{array}$ \\
\hline
\end{tabular}

\subsection{Cascade Heat Pump}

The cascade heat pump system consists of two refrigerant cycles: the low-stage and high-stage cycles connected via a cascade heat exchanger. The cascade heat exchanger works as a condenser for the low-stage cycle and as an evaporator for the high-stage cycle. An example of a cascade air-to-water heat pump can be found in Figure 14.

The main advantage of the cascade heat pump is that two different refrigerants are used in two separate cycles, and they can work at their optimum range of operating conditions. R404A or R410A, having low critical temperatures, are usually used in the low-stage cycle to absorb heat from the ambient air by evaporation, while R134a or R123, having high critical temperatures, are generally used as the refrigerant to produce hot water in the high-stage cycle [72]. The conventional single-stage air-to-water heat pumps suffer from the declined heating capacity at low ambient temperatures, while the cascade air-towater heat pumps can have a smaller compression ratio and lower discharge temperature, 
resulting in higher system performance due to the optimized refrigerant combination and the cascade heat exchanger [73]. On the other hand, the cascade heat pump cycle is difficult to reverse to provide space cooling unless a second outdoor coil is added to the system [72]. Table 5 presents the summary of studies of cascade air-to-water heat pump systems.

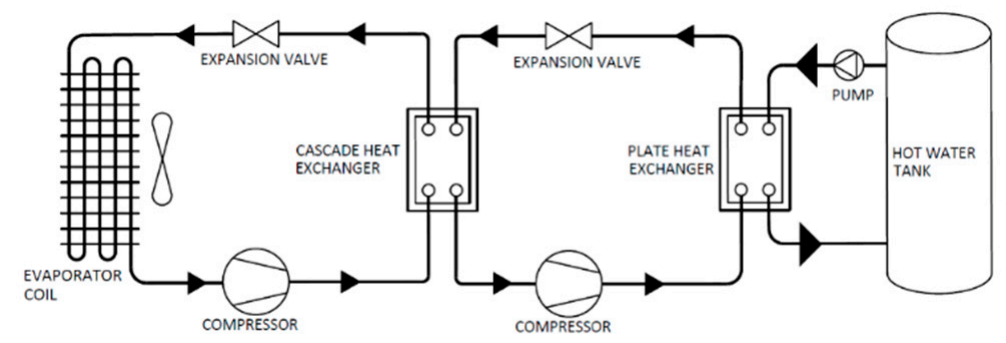

Figure 14. Schematic of the cascade air-to-water heat pump system.

Table 5. Summary of studies of cascade air-to-water heat pump systems.

\begin{tabular}{|c|c|c|}
\hline References & System Designs & Performance \\
\hline [74] & $\begin{array}{l}\text { Cascade air-to-water } \\
\text { heat pump } \\
\text { Load: space heating } \\
\text { and DHW } \\
\text { Region: the UK }\end{array}$ & $\begin{array}{c}\text { COP: almost below } 2.5 \\
\text { Operating costs: higher than gas boiler and } 90 \% \\
\text { efficiency oil boilers } \\
\text { Carbon emissions: } 14 \% \text { and } 57 \% \text { less than gas } \\
\text { and oil boilers, respectively }\end{array}$ \\
\hline [75] & $\begin{array}{l}\text { Cascade air-to-water } \\
\text { heat pump } \\
\text { Load: space heating } \\
\text { Region: China }\end{array}$ & $\begin{array}{l}\text { COP: ranging from } 1.70 \text { to } 2.48 \\
\text { Operating costs: } 17 \% \text { and } 46 \% \text { lower than the } \\
\text { gas boiler and direct electric heater, respectively } \\
\text { at the ambient temperature of }-10^{\circ} \mathrm{C} \\
\text { Carbon emissions: } 2.43 \text { times more than the gas } \\
\text { boiler and } 41 \% \text { less than the direct electric heater }\end{array}$ \\
\hline [73] & $\begin{array}{l}\text { Cascade air-to-water } \\
\text { heat pump } \\
\text { Load: space heating } \\
\text { Region: Korea }\end{array}$ & COP: ranging from 1.95 to 3.4 \\
\hline [76] & $\begin{array}{l}\text { Cascade air-to-water } \\
\text { heat pump } \\
\text { Load: space heating } \\
\text { and DHW } \\
\text { Region: Korea }\end{array}$ & $\begin{array}{l}\text { COP: ranging from } 2.7 \text { to } 3.3 \\
\text { Heating capacity: The cascade heat pump has a } \\
\text { higher and more stable heating capacity than the } \\
\text { single-stage heat pump. }\end{array}$ \\
\hline
\end{tabular}

A techno-economic assessment of a cascade air-to-water heat pump, retrofitted into the UK residential buildings for space and DHW heating, was carried out by simulation [74]. The results showed that the cascade air-to-water heat pump yielded a COP lower than 2.5 at ambient temperatures of $-11.2{ }^{\circ} \mathrm{C}$ to $29.5^{\circ} \mathrm{C}$, and its operating costs were higher than gas boilers and $90 \%$ efficiency oil boilers, but its carbon emissions were $14 \%$ and $57 \%$ less than gas and oiler boilers, respectively. In another study, the energy and economic performance of a cascade air-to-water heat pump for producing high-temperature water $\left(75^{\circ} \mathrm{C}\right)$ at low ambient temperatures were investigated experimentally [75]. The results showed that The COP of the cascade heat pump increases as the ambient temperature rises but decreases as the water supply temperature rises. A numerical and experimental study of a cascade air-to-water heat pump was conducted to determine the optimum intermediate temperature [73]. The results found that the optimum intermediate temperature of the cascade heat pump rises with the increase in ambient and water inlet temperature, as well as the heating capacity. In addition, the performance of a cascade heat pump water heater and a single-stage heat pump was experimentally compared [76]. The results found that the cascade heat pump could achieve a higher and more stable heating capacity than the single-stage heat pump. 


\subsection{Two-Stage Heat Pumps}

As previously stated, the COP and heating capacity of conventional ASHPs can decrease at low ambient temperatures due to the increased compression ratio. The twostage heat pump with an intercooler or a sub-cooler (economizer) is another feasible method to address the problem of the declined performance of ASHPs in cold climates [72]. An example of a two-stage air-to-water heat pump with a sub-cooler can be found in Figure 15.

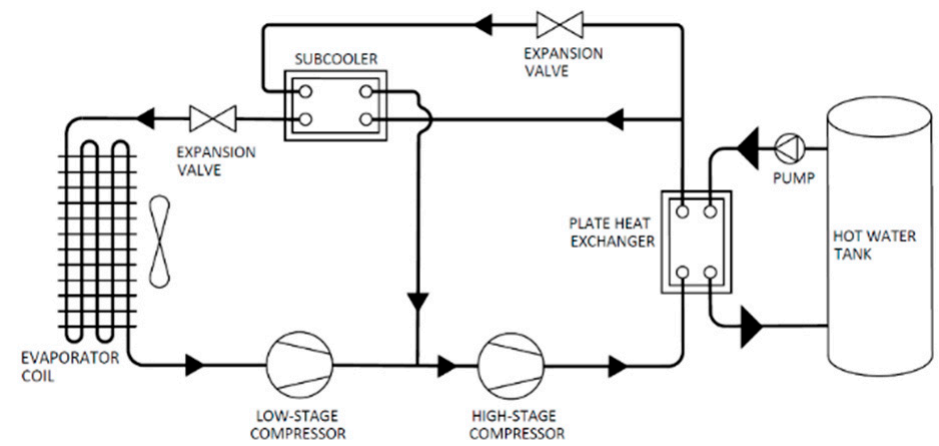

Figure 15. Schematic of the two-stage air-to-water heat pump with a sub-cooler.

It consists of two compressors (low-stage and high-stage), two expansion valves, a sub-cooler, an evaporator coil for absorbing heat from the ambient environment, and a plate heat exchanger for producing hot water. The refrigerant discharged from the low-stage compressor is mixed with the two-phase refrigerant from the sub-cooler and enters the high-stage compressor in a saturated vapour state, so the discharge temperature of the high-stage compressor can be reduced. Moreover, the remaining condensed refrigerant from the plate heat exchanger is supercooled by the two-phase refrigerant in the sub-cooler before entering the expansion valve and the evaporator coil so that the COP of the system can be increased. On the other hand, appropriate control of the two-stage heat pump can be a challenge [72]. Table 6 presents the summary of studies of two-stage heat pump systems.

Table 6. Summary of studies of two-stage heat pump systems.

\begin{tabular}{|c|c|c|}
\hline References & System Designs & Performance \\
\hline [77] & $\begin{array}{l}\text { Two-stage water-to-water } \\
\text { heat pump } \\
\text { Load: district heating }\end{array}$ & $\begin{array}{l}\text { COP: ranging from } 2.6 \text { to } 4.2 \text {. } \\
\text { COP was increased by approximately } 23 \% \text { when } \\
\text { increasing the heat source temperature by } 20^{\circ} \mathrm{C} \\
\text { from a temperature of } 10^{\circ} \mathrm{C} \text {. } \\
\text { Heating capacity: dropped by around } 2 \% \text { when } \\
\text { the low stage compressor inlet superheat was } \\
\text { increased by } 9^{\circ} \mathrm{C} \text { from } 2^{\circ} \mathrm{C} \text {. }\end{array}$ \\
\hline$[72]$ & $\begin{array}{l}\text { Two-stage ASHP } \\
\text { Load: space heating, space } \\
\text { cooling and DHW }\end{array}$ & $\begin{array}{l}\text { COP: ranging from } 3.3 \text { to } 4.2 \text { in cooling mode; } \\
\text { ranging from } 2.3 \text { to } 3.2 \text { in heating mode. } \\
\text { Installation costs: The cost of this two-stage } \\
\text { ASHP is significantly higher than the } \\
\text { single-stage ASHP, but lower than the GSHP. }\end{array}$ \\
\hline [78] & $\begin{array}{l}\text { Two-stage variable } \\
\text { capacity ASHP } \\
\text { Load: space heating and } \\
\text { space cooling }\end{array}$ & $\begin{array}{l}\text { COP: The cooling COP ranged from } 4.7 \text { to } 5.7 \\
\text { with the ambient temperature of } 34^{\circ} \mathrm{C} \text { to } 15^{\circ} \mathrm{C} \text {. } \\
\text { The heating COP ranged from } 1.7 \text { to } 5.0 \text { with the } \\
\text { ambient temperature of }-19^{\circ} \mathrm{C} \text { to } 9{ }^{\circ} \mathrm{C} \text {. }\end{array}$ \\
\hline
\end{tabular}

A two-stage water-to-water heat pump performance with a sub-cooler used for district heating was assessed under various operating conditions [77]. The test results discovered that the COP of the heat pump could be increased with the increase in the heat source temperature, but the refrigerant flow rate and the heating capacity decrease with the rise in the superheating at the low-stage compressor. In another study, a two-stage ASHP applied 
for space conditioning and DHW heating was developed and tested [72]. The results indicated that the heating capacity of the two-stage heat pump is approximately twice that of the single-stage ASHP, but its installation costs are significantly higher. In addition, a two-stage variable capacity ASHP was modelled and tested by simulation [78]. The results showed that the cooling COP ranged from 4.7 to 5.7 when the ambient temperature was $34{ }^{\circ} \mathrm{C}$ to $15^{\circ} \mathrm{C}$, and the heating COP ranged from 1.7 to 5.0 when the ambient temperature was $-19^{\circ} \mathrm{C}$ to $9^{\circ} \mathrm{C}$.

\subsection{Thermally Driven Heat Pumps}

In addition to electric-powered heat pumps, some heat pumps are driven by thermal energy, such as absorption and adsorption heat pumps. They can be used in the residential sector, but most are used in the industrial sector. Absorption heat pumps are thermally driven devices that recover heat from a low-temperature heat source to a high-temperature sink for space heating, cooling, and hot water production, realizing waste heat recovery and utilization [79]. This system mainly consists of a generator, an absorber, an evaporator, a condenser, and other auxiliary equipment. The thermodynamic properties of working fluids can significantly impact the system performance of absorption heat pumps [80]. Ammonia/water and water/lithium bromide are the two most common working fluid combinations used in absorption heat pumps. Thermal energy from a variety of sources can be applied to drive absorption heat pumps, such as steam, solar energy, heat generated by direct combustion fuel (gas, oil), or even waste heat hot water. Absorption heat pumps have proved to be effective in improving the thermal efficiency of gas boilers. An absorption heat pump integrated with a natural gas-fired boiler was developed for improving boiler efficiency through recovering waste heat [79]. The results showed that boiler efficiency could be increased by up to $10 \%$ by waste heat recovery. In addition, a full-open absorption heat pump was proposed for recovering the waste heat of flue gas and used for district heating [81]. The results indicated that the maximum COP and recovery efficiency were 1.62 and 0.63 , respectively.

Adsorption heat pumps are another environmentally friendly and thermally driven system, in which adsorption is used to compress steam from low to high pressure, and refrigerant absorption molecules reversibly combine with solid adsorbents [82]. It can be applied for heating and cooling purposes by utilizing thermal energy from solar energy, geothermal energy, or waste heat generated in industrial processes. The basic adsorption heat pump system mainly includes an adsorber, where the adsorbent material is coated on a surface, a condenser, an evaporator, and an expansion valve. The silica gel/water, zeolite/water, and activated carbon/ammonia are three common working fluid combinations in adsorption heat pumps. This type of heat pump has several advantages. For example, it can utilize thermal energy from abundant heat sources; it can be applied as a thermal energy storage system, and it is environmentally friendly because it does not contain materials that are harmful to the environment [83]. The main disadvantages include low COP values and intermittent operation. Two prototypes of an adsorption heat pump and chiller, with silica gel-water as working fluid, were developed for space heating and air-conditioning [84]. The results indicated that the COPs for heating and cooling were 1.5 and 0.5 , respectively.

\subsection{Comparison of Different Heat Pumps}

Heat pumps have proven to be an effective technology to replace conventional heating and cooling systems in residential buildings. Several different heat pumps have been introduced in previous sections, including ASHP, WSHP, GSHP, SAHP, cascade heat pump, two-stage heat pump, and other thermally driven heat pumps. Because thermally driven heat pumps are not commonly used in residential buildings. This section mainly compares and summarizes the advantages and disadvantages of commonly used heat pumps in households. Table 7 summarizes the pros and cons of these heat pumps. 
Table 7. Summary of pros and cons of various heat pumps.

\begin{tabular}{|c|c|c|}
\hline Heat Pumps & Pros & Cons \\
\hline $\begin{array}{l}\text { Air Source } \\
\text { Heat Pump }\end{array}$ & $\begin{array}{l}\text { Simple operation and low } \\
\text { installation costs } \\
\text { Less primary energy consumption } \\
\text { and GHG emissions than } \\
\text { conventional } \\
\text { fossil-fuel-based systems }\end{array}$ & $\begin{array}{l}\text { Frost formation on the outside } \\
\text { evaporator at low ambient } \\
\text { temperatures } \\
\text { Heating capacity and COP may } \\
\text { decrease under cold climates. }\end{array}$ \\
\hline $\begin{array}{l}\text { Water Source } \\
\text { Heat Pump }\end{array}$ & $\begin{array}{l}\text { Can utilize heat from abundant } \\
\text { sources, such as rivers, ponds, } \\
\text { and lakes } \\
\text { Higher COP and energy efficiency } \\
\text { ratio (EER) than ASHPs }\end{array}$ & $\begin{array}{l}\text { Surface water temperature is affected } \\
\text { by climate variations. } \\
\text { Low water quality may cause the } \\
\text { blockage, corrosion, and fouling of } \\
\text { heat exchangers. } \\
\text { Water availability can restrict the use } \\
\text { of WSHPs. }\end{array}$ \\
\hline $\begin{array}{l}\text { Ground Source } \\
\text { Heat Pump }\end{array}$ & $\begin{array}{l}\text { Highly efficient systems } \\
\text { Higher COP and greater energy } \\
\text { savings than ASHPs } \\
\text { More suitable to be applied in than } \\
\text { ASHPs in cold climates } \\
\text { Significant GHG emissions } \\
\text { reductions compared to } \\
\text { fossil-fuel-based systems. }\end{array}$ & $\begin{array}{c}\text { High installation costs or } \\
\text { land requirement } \\
\text { Potential leaks of refrigerant and } \\
\text { antifreeze solutions } \\
\text { Metal corrosion of GHEs } \\
\text { System performance may be affected } \\
\text { by underground heat accumulation } \\
\text { and depletion. }\end{array}$ \\
\hline $\begin{array}{l}\text { Solar Assisted } \\
\text { Heat Pump }\end{array}$ & $\begin{array}{l}\text { Significant environmental benefits } \\
70 \% \text { of energy savings can } \\
\text { be achieved. } \\
\text { Higher-temperature heat being } \\
\text { delivered to heat pumps }\end{array}$ & $\begin{array}{l}\text { Solar intermittency restricts the } \\
\text { system performance } \\
\text { Requires complex control system } \\
\text { Relatively high installation costs }\end{array}$ \\
\hline $\begin{array}{l}\text { Cascade Heat } \\
\text { pump }\end{array}$ & $\begin{array}{c}\text { Higher heating capacity and COP } \\
\text { than single-stage heat pumps } \\
\text { Can operate efficiently under } \\
\text { cold climates } \\
\text { Great GHG emissions reduction } \\
\text { compared to fossil-fuel-based systems }\end{array}$ & $\begin{array}{l}\text { Higher installation cost, } \\
\text { Higher operating costs than } \\
\text { fossil-fuel-based systems } \\
\text { Hard to add a four-way valve to } \\
\text { achieve heating or cooling }\end{array}$ \\
\hline $\begin{array}{l}\text { Two Stage } \\
\text { Heat Pump }\end{array}$ & $\begin{array}{c}\text { Higher COP and heating capacity } \\
\text { than conventional ASHPs } \\
\text { Can operate efficiently under } \\
\text { cold climates }\end{array}$ & $\begin{array}{l}\text { Significantly higher costs than ASHPs } \\
\text { Requires appropriate control logic }\end{array}$ \\
\hline
\end{tabular}

ASHPs have the advantages of simple operation, low installation costs, and less primary energy consumption and GHG emissions than conventional fossil-fuel-based systems, but their performance degradation and frost formation at low ambient temperatures must be considered. Auxiliary heating devices may be required for ASHPs in winter conditions. Consequently, ASHPs are more suited to buildings in areas with mild climates.

WSHPs can have higher COP and EER than ASHPs because water has better heat transfer and thermal properties. Moreover, WSHPs can take advantage of abundant sources, such as rivers, ponds, and lakes. On the other hand, the temperature variation of surface water under different climates can be a disadvantage. The availability of groundwater and surface water can restrict the widespread use of WSHPs. Moreover, low water quality may lead to the blockage, corrosion, and fouling of heat exchangers. Thus, WSHPs are more suitable for buildings in areas with sufficient and high-quality water bodies.

GSHPs have the merits of high COP, excellent system performance, and significant energy savings. Vertical GCHPs and DX-GSHPs can perform better than horizontal ones, but high initial cost due to borehole drilling is a drawback. The land area required can be a disadvantage for horizontal GCHPs. Possible leaks of refrigerant and antifreeze solution and metal corrosion may have a severe impact on the environment. More importantly, 
GSHPs can have better system performance than ASHPs in areas with extremely hot or cold climates because the ground has a yearly constant temperature. Heat accumulation and depletion, due to long-term operation, may degrade the system performance. Therefore, GSHPs are better suited for buildings in areas with hot or cold climates.

SAHPs have the benefits of great energy savings, excellent system performance, and significant environmental benefits. SAHPs can obtain a higher rate because both solar energy and ambient air can be used as heat sources. However, solar intermittency may reduce the performance of SAHPs. As a result, SAHPs are more appropriate to be used for buildings in areas with sufficient solar radiation.

Cascade heat pumps have the advantages of higher heating capacity, high COP, and great GHG emissions reduction, and they can operate efficiently under cold climates. However, higher installation costs can be an issue. Additional cooling devices need to be integrated with cascade heat pumps to achieve both heating and cooling. Thus, cascade heat pumps can be applied in areas with cold climates.

Two-stage heat pumps can have higher COP and heating capacity than conventional ASHPs and operate efficiently under cold climates, but they require more complex control logic and are significantly more costly than ASHPs. Therefore, two-stage heat pumps can be used in areas with cold climates.

\section{Heat Pump End-Uses}

Heat pumps can be applied in many applications. Based on their fundamental operation principle, heat pumps can be used to offer heating, cooling, and hot water heating in residential, commercial, and industrial buildings. Moreover, heat pumps can be used in industrial applications, such as drying and food making, using industrial waste heat as a heat source. Coupling heat pumps with thermal storage systems can achieve load shifting for buildings and peak load shaving on electrical networks [24]. Combining solar PV systems with heat pumps can be a practical approach in increasing the self-consumption of PV generation and achieving the NZEB target $[33,56]$.

\subsection{Heat Pumps Coupled with Thermal Energy Storage}

Combining heat pumps with heat storage systems offers clients economic benefits and will play an essential role in a low-carbon future. Integrating heat pumps and thermal storage technologies can manage electric energy loads by shifting heating and cooling demands to a period with low electricity prices, leading to cost savings [24]. Furthermore, by coupling heat pumps and thermal storage with solar PV systems, heating or cooling can be provided by consuming renewable energy electricity, reducing GHG emissions.

A heating system was modelled to consume excess renewable electricity for space heating and DHW production [85]. A heat pump with thermal storage at the district level, a natural gas-fired boiler, and electric resistance heaters were included in the model. The results suggested that heat pumps with storage units achieve the lowest running cost even when a charge for excess electricity is applied. Some researchers have also tried to increase the efficiency of heat pumps with storage tanks. A heat pump coupled with a heat storage tank filled with PCM was developed and used for summer space cooling [86]. Compared to the standard water tank, the results indicated that $14.5 \%$ more cold energy and $20.65 \%$ longer temperature comfort could be supplied by a heat pump with a PCM storage tank.

Applying heat pumps with thermal energy storage for heating or cooling can shift the burden on the electrical network to off-peak hours. An air-source heat pump with PCM tanks for load shifting was compared to the case without load shifting or thermal storage [87]. The results indicated that shifting loads of fifty heat pumps with storage tanks, entirely to off-peak hours, increased the electric loads on networks by over $50 \%$ compared to the reference case. In such cases, appropriate demand-side management (DSM) needs to be integrated into residential heat pumps to reduce the peak loads on the electricity grid and enable a stable operation of heat pumps [19]. 


\subsection{Heat Pumps with Solar PV Systems}

\subsubsection{The Increase of Self-Consumption}

Solar PV systems are being increasingly applied worldwide to reduce fossil fuel consumption and the environmental burdens of residential buildings [18]. Major issues behind the household solar PV systems are intermittency and the mismatch between the PV production and household loads [33]. On the other hand, maximum PV production corresponds to peak electricity prices, so dwellers are encouraged to increase the use of PV electricity. Energy storage systems, such as heat pumps, coupled with thermal energy storage tanks and electrical batteries are two viable solutions to increase the use of PV generation.

Eight control strategies to increase the self-consumption ratio of local PV generation focusing on heat pump operation and electrical battery are considered in [17]. The results indicated that the self-consumption ratio increased by $37 \%$ in the optimal scenario, but whether to increase the self-consumption of PV generation depends on the difference between FiTs and local purchasing price. The increased self-consumption ratio can lead to cost savings when the FiTs are lower than the buying price. DSM was adopted to enhance the self-consumption of domestic PV systems by incorporating heat pumps and thermal energy storage for a household in Germany [19]. The authors found that $55 \%$ to $65 \%$ of self-consumption levels can be achieved with a PV plant of $5.5 \mathrm{kWp}$ for a household with low to medium thermal insulation standards.

Based on instantaneous PV production, a ruled-based control strategy was proposed for an air-to-water heat pump that is used for space heating and DHW consumption [4]. In this strategy, the thermal capacity of the building is used as a virtual battery, and the heat pump is operated to its maximum capacity to take advantage of its heat storage capacity. The results showed that, when compared to the base model using the standard control approach, the rule-based control strategy could raise the self-consumption and self-sufficiency ratios from $7 \%$ to $60 \%$ and $12 \%$ to $65 \%$, respectively. Moreover, a heat pump system combined with electrical and thermal energy storage systems was designed to achieve higher PV self-consumption [10]. They discovered that installing an $800 \mathrm{~L}$ water tank and an $8 \mathrm{kWh}$ battery could compensate for more than $40 \%$ of the electricity consumption for DHW production and house loads. In addition, it is essential to note that compared with electrical energy storage, a heat pump with thermal energy storage can be more cost-effective. It has been discovered that the initial cost of using heat pumps with electricity storage is four times higher than that with thermal energy storage [18].

\subsubsection{System Optimisation}

The performance of integrated solar PV and heat pumps is highly influenced by the increased instability caused by peak loads of heat pumps and fluctuating PV generation. Advanced control strategies on optimizing the combined performance of heat pumps and PV systems may be required. Smart control algorithms were developed for a PV system and heat pump used for space heating and DHW production, considering the weather forecasts and timely electricity prices [88]. The authors found that the smart control strategy can contribute to $26.4 \%$ of final energy reduction, $60 \%$ of the self-consumption increase and $15 \%$ of the net annual electricity cost reduction compared to the case with independent PV and heat pump. Similarly, a predictive control-based multi-objective optimization energy management concept was proposed for a PV system combined with heat pumps, heat storage, and batteries [89]. This concept was designed to reduce operational costs and power exchange with the power grid while ensuring comfort for the user. The results proved the viability of this concept. In addition, a novel heuristic control algorithm was proposed to optimize heat pump management for a single-family house with a $3 \mathrm{kWp}$ PV system, and a $1 \mathrm{~kW}$ air-to-water heat pump, by considering the accurate consumption data [90]. The results indicated that this novel algorithm could work 1000 times faster in optimizing heat pump management, lead to $49 \%$ cost savings, and provide a $5 \%$ SCR increase compared to other programs. 


\subsubsection{Net Zero Energy Buildings}

The concept of NZEBs has been used to reduce energy consumption and GHG emissions in the building sector. NZEBs can be defined as buildings that produce as much energy as they consume annually. They can be achieved through different strategies, such as passive strategies, renewable generation systems, and energy-efficient technologies. Solar PV and heat pump systems can make viable contributions and have attracted a great deal of research interest.

The performance of solar PV in different climates in the US with different heating, ventilation, and air conditioning (HVAC) systems for a residential NZEB was compared by simulation [56]. The authors found that GSHPs could reduce energy consumption by approximately $25-40 \%$ compared with ASHPs in cold climates. Meanwhile, another study found that a smaller PV system is required for GSHPs than ASHPs to achieve the NZEB target in a mixed-humid climate zone in the US [91]. A new system, consisting of PV double-skin façade combined with an ASHP, was proposed for offering space heating and DHW heating by consuming renewable energy [92]. The results found that most of this collaborative design system can satisfy $98.5 \%$ of annual heating demand, with the remaining $1.5 \%$ being offered by natural gas, almost achieving a NZEB.

As SAHPs can use both solar energy and ambient air as heat sources to provide heating, they may also be an efficient way of achieving NZEBs. A techno-economic analysis was conducted for an intelligent hybrid system, comprising a hybrid solar collector and the DX-SAHP, to satisfy electricity and heating demands [60]. The results of the analysis summarized this hybrid system's cost and system performance compared to other conventional heating systems and solar PV combined with heat pump systems.

\section{Environmental Aspects of Heat Pumps}

Several studies show that heat pumps could lead to significant energy savings and reduce GHG emissions $[31,34,45,93]$. Therefore, they are one of the most promising technologies to decarbonize the energy sector. However, heat pumps still have issues that may impact the environment, such as refrigerant use and leakage problems.

\subsection{Natural Refrigerants}

Conventional heat pumps use hydrofluorocarbons (HFCs) as refrigerants with high GWP values. The Montreal Protocol represents the global agreement to protect the earth's ozone layer by requiring the phasing out of HFCs that are supposed to contribute to GHG emissions [13]. In this case, natural refrigerants with low GWP and zero ODP are recommended to be used in heat pump applications. The natural refrigerant, R290, could be an excellent alternative for R22 in refrigeration systems because of its outstanding environmental and thermophysical characteristics [15]. For example, an investigation on different refrigerants used in ASHP for space heating found that 11\% of GHG emissions reduction can be achieved using R290 compared to R22 [12]. In addition, an evaluation of heat pumps using R600a concluded a valuable long-term low-GWP substitute for the HFC refrigerants in heat pump applications [13].

R744 is another natural refrigerant with little impact on climate because it can be retrieved from manufacturing processes. R744 possesses the most desirable environmental potentials among all alternatives due to its low GWP, non-flammability, and non-toxicity [14]. The effects of a semi-hermetic two-stage compressor using R744 as the refrigerant was analysed [1]. The results illustrated that GHG emission generation is competitive using R744 compared to the other refrigerants currently being used in heat pumps.

\subsection{Leakage}

Water mixed with antifreeze solution is generally employed as a heat transfer fluid in the closed-loop surface water heat pumps and GCHP systems to avoid freezing in winter. According to [49], these antifreeze liquids mainly include glycol, methanol, ethanol, etc. This can inevitably lead to a concern that surface water or groundwater can be contaminated 
due to pipe leaks [57]. To ensure the environmental compatibility of antifreeze solutions in borehole heat exchangers, more research should be conducted to analyse the influence of additives on groundwater quality and subsurface microbial activity [43]. Similarly, due to long-buried refrigerant loops, the refrigerant leak can cause the same problem for DX-GSHP systems [53]. Refrigerant leak can be solved by using R744 as the refrigerant due to its non-toxicity and non-flammability [94]. Apart from this concern, some other issues caused by installing GSHPs were summarized in, including soil subsidence and wells drying up, caused by the falling water level, and potential hazards to drilling labourers and residents because of near-surface gas reserves, etc.

\section{Economic Aspects of Heat Pumps}

The cost of a heat pump is vital in determining its use. The installation and economic viability of heat pumps rely heavily on different aspects, including climate conditions, locations, local policies, and market prices [3]. Heat pumps may be more expensive than other heating or cooling devices. Better system performance, environmental characteristics, and operating costs may compensate for this drawback.

Among all heating technologies, ASHPs are economically sensible replacements for coal-fired boilers for space heating due to the low initial and operation cost and the high energy efficiency [31]. Similarly, a techno-economic analysis, using a mathematic model established in northern China, found that ASHPs are the most economical of all heating candidates [35]. Another experiment found that the use of GSHP in space heating could contribute to more than $70 \%$ of fuel savings and $45 \%$ of GHG emissions reduction compared to natural gas furnaces [45]. An experiment found that GCHPs can save up to $60 \%$ of energy more than a conventional ASHP system [47]. In contrast, a study in Iran argued that GSHP is indeed not preferred in Iran due to the high cost of electricity and heat pump components and the low prices of natural gas [55]. It can be argued that heat pump systems have economic merits compared to alternative heating devices, but the results may vary based on various circumstances.

To further compare the costs of other commonly used heat pumps, Table 8 is provided that summarizes the capital and operational costs of various heat pumps.

Table 8. Cost comparison among various heat pumps.

\begin{tabular}{|c|c|c|c|c|c|c|c|}
\hline \multirow{2}{*}{ Heat Pumps } & \multicolumn{3}{|c|}{ Capital Costs } & \multicolumn{3}{|c|}{ Operational Costs } & \multirow{2}{*}{ Comments } \\
\hline & High & Medium & Low & High & Medium & Low & \\
\hline $\begin{array}{l}\text { Air Source } \\
\text { Heat Pumps }\end{array}$ & & & $\sqrt{ }$ & & $\sqrt{ }$ & & $\begin{array}{l}\text { AHSPs are selected as the reference case with the lowest } \\
\text { capital costs due to their simple design and medium } \\
\text { operational costs. }\end{array}$ \\
\hline $\begin{array}{l}\text { Water Source } \\
\text { Heat Pumps }\end{array}$ & & $\sqrt{ }$ & & & $\sqrt{ }$ & & $\begin{array}{l}\text { The capital costs of WSHPs are higher than ASHPs due to } \\
\text { additional costs for labour, heat exchangers, water coils, } \\
\text { pumps, and so on. The operational costs are lower than } \\
\text { ASHPs but higher than GSHPs. }\end{array}$ \\
\hline $\begin{array}{l}\text { Ground Source } \\
\text { Heat Pumps }\end{array}$ & $\sqrt{ }$ & & & & & $\sqrt{ }$ & $\begin{array}{l}\text { GSHPs have the highest capital cost due to drilling } \\
\text { boreholes, installing GHEs, and purchasing equipment, but } \\
\text { their operational costs are significantly lower than ASHPs. }\end{array}$ \\
\hline $\begin{array}{c}\text { Solar Assisted } \\
\text { Heat Pumps }\end{array}$ & $\sqrt{ }$ & & & & & $\sqrt{ }$ & $\begin{array}{l}\text { Based on different design configurations, the capital costs of } \\
\text { SAHPs are higher than ASHPs and WSHPs due to the use } \\
\text { of solar collectors, heat storage tanks, pumps, etc., but lower } \\
\text { than GSHPs. }\end{array}$ \\
\hline $\begin{array}{l}\text { Cascade Heat } \\
\text { pumps }\end{array}$ & & $\sqrt{ }$ & & $\sqrt{ }$ & & & $\begin{array}{l}\text { Cascade heat pumps have higher capital and operational } \\
\text { costs than ASHPs because of more system components and } \\
\text { power consumption. }\end{array}$ \\
\hline $\begin{array}{l}\text { Two-Stage } \\
\text { Heat Pumps }\end{array}$ & & $\sqrt{ }$ & & $\sqrt{ }$ & & & $\begin{array}{c}\text { Similar to cascade heat pumps, the capital costs and } \\
\text { operational costs of two-stage heat pumps are higher } \\
\text { than ASHPs. }\end{array}$ \\
\hline
\end{tabular}


There is a concern regarding the high initial costs of GSHPs and whether they are economically justified. While it is not the intent of this paper to provide an economic or life-cycle analysis in comparing different heat pump types, we do believe that it is necessary to define where and when the selection of ground sourced heat pump might be considered. For the case of two totally different climates, Sydney vs. Chicago, we consider the Heating Degree Day (HDD) and Cooling Degree Hour (CDH) information, as taken from the ASHRAE Fundamentals Handbook (2017) on climate data (see Table 9) below.

Table 9. Monthly climatic design conditions of Sydney and Chicago [95].

\begin{tabular}{cccc}
\hline Location & Annual Avg. Temp. & HDD 10.0 ${ }^{\circ} \mathbf{C}$ & CDH 23.3 ${ }^{\circ} \mathbf{C}$ \\
\hline Sydney, Australia & $18.3^{\circ} \mathrm{C}$ & 1 & 2566 \\
\hline Chicago, IL, USA & $11^{\circ} \mathrm{C}$ & 1639 & 2056 \\
\hline
\end{tabular}

The annual average ambient dry-bulb temperature represents a good indication of what the ground annual temperature is $2-3 \mathrm{~m}$ below the surface, varying $\pm 3{ }^{\circ} \mathrm{C}$ (Climate Consultant software). Furthermore, it may be important to observe the extremes of the two climates, where for heating, an ambient of $5.6^{\circ} \mathrm{C}$ for Sydney and a $-19.6^{\circ} \mathrm{C}$ for Chicago are observed for winter periods. Noted from this data is that Sydney doesn't have a heating problem while both cities do have a significant cooling requirement. The COP of a good quality air-to-air or air-to-water system can function very effectively within the climatic limits of Sydney. Yet, both cities experience a similar cooling problem.

The amount of both HHD and CDH for Chicago is relatively high, indicating a heating and cooling requirement. Further to this is the recognition of the extremes, where up to a $30{ }^{\circ} \mathrm{C}$ temperature difference in the ground is experience from that of an ambient temperature, for Chicago. These considerations would imply that Chicago would greatly benefit from a GSHP where COP values would remain high during extreme ambient conditions.

Some other studies also prove that GSHPs can be more cost-effective than ASHPs in extreme climates. A techno-economic analysis of a GSHP, and an ASHP used for space heating and cooling, was carried out in Saudi Arabia with a hot, dry climate [54]. The result showed that the GSHP could obtain a total $40 \%$ cost reduction compared to the ASHP, and the GSHP can achieve free heating due to the constant underground temperature of $29^{\circ} \mathrm{C}$, which is higher than the required indoor temperature of $26^{\circ} \mathrm{C}$.

\section{Conclusions: Overview and Suggestion}

This review article covers a broad range of topics published in relation to electrified heat pumps that can be applied and are suitable for residential projects. Two distinct areas are identified from the literature: first, the technology centred on heat pumps themselves; second, the design uses, applications, policies, and global impacts that heat pumps can offer. We have basically left the policies and global impacts for others to define. It is evident that heat pumps are important devices in the shift to carbon-neutral building conditioning and therefore serve a significant purpose towards this goal. To consider which heat pump to apply in a specific project, it is important to better understand the vast range of types, how they operate, and what additional advantages they can provide. If running a system on renewable (solar PV) energy is required, we might also consider the aspect of self-consumption of this generated energy, as FiTs become less attractive. Therefore, understanding the type of heat pump system, such as one that can provide hot water to the sink, is essential. In other words, does the system allow for thermal energy storage?

Climatic conditions are another reason for the selection of heat pump types. Under extreme ambient winter and summer climatic conditions, consideration might be given to where the energy source is coming from. In other words, the ground or a water body would have a smaller temperature range than that of the air. In extreme climatic conditions, 
heat pumps that consider the source and access to it may be more economically viable since they can yield much higher COP than, for example, air-to-air heat pumps.

It is realized that as the technology of heat pumps continues to develop with higher COP performance and improved environmental consideration, the move towards natural refrigerants, such as R744, is becoming more common. This paper did not confront the evaluation of refrigerants in terms of their performance, optimal temperature ranges, $\mathrm{COP}$, etc. We acknowledge that there is an entire range of future studies required here. At present, we are working with a few associations and manufacturers that are privy to this subject but are unable to release conclusive information.

Towards the end of this article, several design innovations were introduced, such as cascade or dual heat pumps and those utilizing solar thermal or even operating under electrical solar PV generated energy. This indicates the huge development and research potential offered by the heat pump concept. Solar energy incorporation and technical advancements into the refrigeration cycle itself are continuously being researched worldwide. The inclusion of suction valves, electronic expansion valves, shell-in-tube (and other) heat exchangers, variable speed drive (DC inverter) compressors, as well as other innovations will no doubt continue to raise the COP of heat pumps in the future. Successful technologies must become mainstream in the design of future heat pumps as we continue to strive for NZEBs. There is no doubt that we are already on the pathway to do so; only $5 \%$ of the world's total potential of heat pump installations has taken place thus far.

Author Contributions: The paper was a collaborative effort between the authors. Z.W. is the main contributor to the initial draft and revising the following drafts. M.B.L., C.L., M.A. and P.H. contributed equally to the work conceptualization, project administration, writing the initial, and editing the final drafts. All authors have read and agreed to the published version of the manuscript.

Funding: This research received no external funding.

Institutional Review Board Statement: Not applicable.

Informed Consent Statement: Not applicable.

Data Availability Statement: Not applicable.

Acknowledgments: The authors gratefully acknowledge the technical knowledge about the basic refrigeration cycle provided by Jay Dawson, affiliated with Bellarine \& Westcoast Refrigeration.

Conflicts of Interest: The authors declare no conflict of interest.

\section{Abbreviations}

$\begin{array}{ll}\text { Acronym } & \text { Definition } \\ \text { ASHP } & \text { Air source heat pump } \\ \text { ASHRAE } & \text { American Society of Heating, Refrigerating and Air-Conditioning Engineers } \\ \text { CDH } & \text { Cooling degree hour } \\ \text { COP } & \text { Coefficient of performance } \\ \text { DC } & \text { Direct current } \\ \text { DHW } & \text { Domestic hot water } \\ \text { DSM } & \text { Demand side management } \\ \text { DX-GSHP } & \text { Direct expansion-ground source heat pump } \\ \text { DX-SAHP } & \text { Direct expansion-solar assisted heat pump } \\ \text { EER } & \text { Energy efficiency ratio } \\ \text { EU } & \text { European Union } \\ \text { FiTs } & \text { Feed-in tariffs } \\ \text { GCHP } & \text { Ground coupled heat pump } \\ \text { GHE } & \text { Ground heat exchanger } \\ \text { GHG } & \text { Greenhouse gas } \\ \text { GSHP } & \text { Ground source heat pump } \\ \text { GWP } & \text { Global warming potential }\end{array}$




$\begin{array}{ll}\text { HDD } & \text { High degree day } \\ \text { HFCs } & \text { Hydrofluorocarbons } \\ \text { HVAC } & \text { Heating, ventilation, and air conditioning } \\ \text { IX-SAGSHP } & \text { Indirect expansion solar assisted ground source heat pump } \\ \text { IX-SAHP } & \text { Indirect expansion-solar assisted heat pump } \\ \text { NZEBs } & \text { Net zero energy buildings } \\ \text { ODP } & \text { Ozone depletion potential } \\ \text { PCM } & \text { Phase change material } \\ \text { PV } & \text { Photovoltaic } \\ \text { RAC } & \text { Room air conditioning } \\ \text { SAHP } & \text { Solar assisted heat pump } \\ \text { SCOP } & \text { Seasonal coefficient of performance } \\ \text { SWHP } & \text { Surface water heat pump } \\ \text { WSHP } & \text { Water source heat pump } \\ \text { Symbol } & \text { Description } \\ Q_{H} & \text { Heat from the source } \\ Q_{L} & \text { Heat released to the sink } \\ \text { R11 } & \text { Trichlorofluoromethane } \\ \text { R123 } & \text { 1,1-Dichloro-2,2,2-Trifluoroethane } \\ \text { R134a } & \text { 1,1,1,2-Tetrafluoroethane } \\ \text { R22 } & \text { Chlorodifluoromethane } \\ \text { R290 } & \text { Propane } \\ \text { R404A } & \text { R125/R143a/R134a (44/52/4 wt.\%) } \\ \text { R410A } & \text { R32/R125 (50/50 wt. \%) } \\ \text { R600a } & \text { Isobutane } \\ \text { R744 } & \text { Carbon dioxide } \\ T_{H} & \text { Absolute temperature of the heat source of the engine } \\ T_{L} & \text { Absolute temperature of the low temperature exhaust } \\ W & \text { Work } \\ \eta & \text { the Carnot, or ideal efficiency of a heat engine } \\ & \\ & \end{array}$

\section{References}

1. Cavallini, A.; Cecchinato, L.; Corradi, M.; Fornasieri, E.; Zilio, C. Two-stage transcritical carbon dioxide cycle optimisation: A theoretical and experimental analysis. Int. J. Refrig. 2005, 28, 1274-1283. [CrossRef]

2. Liu, B.; Wang, D.; Xu, Y.; Liu, C.; Luther, M. Vertical specialisation measurement of energy embodied in international trade of the construction industry. Energy 2018, 165, 689-700. [CrossRef]

3. Kozarcanin, S.; Hanna, R.; Staffell, I.; Gross, R.; Andresen, G. Impact of climate change on the cost-optimal mix of decentralised heat pump and gas boiler technologies in Europe. Energy Policy 2020, 140, 111386. [CrossRef]

4. Bee, E.; Prada, A.; Baggio, P. Demand-side management of air-source heat pump and photovoltaic systems for heating applications in the italian context. Environments 2018, 5, 132. [CrossRef]

5. Rinaldi, A.; Soini, M.C.; Streicher, K.; Patel, M.K.; Parra, D. Decarbonising heat with optimal PV and storage investments: A detailed sector coupling modelling framework with flexible heat pump operation. Appl. Energy 2021, 282, 116110. [CrossRef]

6. Australian Energy Update. Available online: https://www.energy.gov.au/sites/default/files/Australian\%20Energy\%20Statistic s\%202020\%20Energy\%20Update\%20Report_0.pdf (accessed on 7 June 2021).

7. Space Heating and Cooling. Available online: http://www.energyrating.gov.au/products/space-heating-and-cooling (accessed on 7 June 2021).

8. Valancius, R.; Singh, R.M.; Jurelionis, A.; Vaiciunas, J. A review of heat pump systems and applications in cold climates: Evidence from Lithuania. Energies 2019, 12, 4331. [CrossRef]

9. Bahadori, A.; Nwaoha, C.; Zendehboudi, S.; Zahedi, G. An overview of renewable energy potential and utilisation in Australia. Renew. Sustain. Energy Rev. 2013, 21, 582-589. [CrossRef]

10. Battaglia, M.; Haberl, R.; Bamberger, E.; Haller, M. Increased self-consumption and grid flexibility of PV and heat pump systems with thermal and electrical storage. Energy Procedia 2017, 135, 358-366. [CrossRef]

11. Fleuchaus, P.; Blum, P. Damage event analysis of vertical ground source heat pump systems in Germany. Geotherm. Energy 2017, 5, 1-15. [CrossRef]

12. Chen, X.; Liu, C.; Yang, J.; Chen, J. Experimental study on R-22, R-427A, R-161 and R-290 in air-source heat pump for space heating at low ambient temperatures. Int. J. Refrig. 2018, 96, 147-154. [CrossRef]

13. Longo, G.A.; Mancin, S.; Righetti, G.; Zilio, C.; Brown, J.S. Assessment of the low-GWP refrigerants R600a, R1234ze (Z) and R1233zd (E) for heat pump and organic Rankine cycle applications. Appl. Therm. Eng. 2020, 167, 114804. [CrossRef] 
14. Bolaji, B.; Huan, Z. Ozone depletion and global warming: Case for the use of natural refrigerant-A review. Renew. Sustain. Energy Rev. 2013, 18, 49-54. [CrossRef]

15. Shrivastava, A.P.; Chandrakishor, C. Evaluation of refrigerant R290 as a replacement to R22. Int. J. Innov. Res. Sci. Eng. Technol. 2016, 2, 739-747.

16. Ma, Y.; Liu, Z.; Tian, H. A review of transcritical carbon dioxide heat pump and refrigeration cycles. Energy 2013, 55, 156-172 [CrossRef]

17. Stauffer, Y.; Koch, N.; Hutter, A.; Pflugradt, N.D. Quantifying the potential of smart heat-pump control to increase the selfconsumption of photovoltaic electricity in buildings. In Proceedings of the EuroSun 2018, Rapperswil, Switzerland, 10-13 September 2018.

18. Zator, S.; Skomudek, W. Impact of DSM on energy management in a single-family house with a heat pump and photovoltaic installation. Energies 2020, 13, 5476. [CrossRef]

19. Williams, C.J.; Binder, J.O.; Kelm, T. Demand side management through heat pumps, thermal storage and battery storage to increase local self-consumption and grid compatibility of PV systems. In Proceedings of the 2012 3rd IEEE PES Innovative Smart Grid Technologies Europe (ISGT Europe), Berlin, Germany, 14-17 October 2012; pp. 1-6.

20. Heat Pumps. Available online: https:/ / www.iea.org/reports/heat-pumps (accessed on 17 July 2021).

21. Global Energy Transformation: The Remap Transition Pathway. Available online: https://www.irena.org/-/media/Files/IREN A/Agency/Publication/2019/Apr/IRENA_GET_REmap_pathway_2019.pdf (accessed on 17 July 2021).

22. Xiao, B.; He, L.; Zhang, S.; Kong, T.; Hu, B.; Wang, R. Comparison and analysis on air-to-air and air-to-water heat pump heating systems. Renew. Energy 2020, 146, 1888-1896. [CrossRef]

23. Solar hot Water Rebate. Available online: https: / www.solar.vic.gov.au/solar-hot-water-rebate (accessed on 17 July 2021$)$.

24. Verhelst, C.; Degrauwe, D.; Logist, F.; Van Impe, J.; Helsen, L. Multi-objective optimal control of an air-to-water heat pump for residential heating. Build. Simul. 2012, 5, 281-291. [CrossRef]

25. Zhang, J.; Zhu, X.; Mondejar, M.E.; Haglind, F. A review of heat transfer enhancement techniques in plate heat exchangers. Renew. Sustain. Energy Rev. 2019, 101, 305-328. [CrossRef]

26. Heat Exchanger. Available online: https://loluoch.digitalscholar.rochester.edu/portfolio/Heat\%20Exchangers\%20Van\%20Gogh pdf (accessed on 17 July 2021).

27. Olaiya, K.A.; Alabi, I.O.; Okediji, A.P.; Alonge, O.I. Parametric and quantitative analysis on the development of shell and tube heat exchanger. IJAEMS 2018, 4, 451-459.

28. Hermes, C.J. Heat transfer and pressure drop trade-offs in liquid-to-suction heat exchangers. Int. J. Refrig. 2019, 104, 496-500. [CrossRef]

29. Nasution, D.M.; Idris, M.; Pambudi, N.A. Room air conditioning performance using liquid-suction heat exchanger retrofitted with R290. Case Stud. Therm. Eng. 2019, 13, 100350. [CrossRef]

30. Zhang, Y.; Ma, Q.; Li, B.; Fan, X.; Fu, Z. Application of an air source heat pump (ASHP) for heating in Harbin, the coldest provincial capital of China. Energy Build. 2017, 138, 96-103. [CrossRef]

31. Renaldi, R.; Kiprakis, A.; Friedrich, D. An optimisation framework for thermal energy storage integration in a residential heat pump heating system. Appl. Energy 2017, 186, 520-529. [CrossRef]

32. Kowalski, P.; Szałański, P. Seasonal coefficient of performance of air-to-air heat pump and energy performance of a building in Poland. E3S Web Conf. 2019, 116, 00039. [CrossRef]

33. Bee, E.; Prada, A.; Baggio, P.; Psimopoulos, E. Air-source heat pump and photovoltaic systems for residential heating and cooling: Potential of self-consumption in different European climates. Build. Simul. 2019, 12, 453-463. [CrossRef]

34. Asaee, S.R.; Ugursal, V.I.; Beausoleil-Morrison, I. Techno-economic feasibility evaluation of air to water heat pump retrofit in the Canadian housing stock. Appl. Therm. Eng. 2017, 111, 936-949. [CrossRef]

35. Zhang, Q.; Zhang, L.; Nie, J.; Li, Y. Techno-economic analysis of air source heat pump applied for space heating in northern China. Appl. Energy 2017, 207, 533-542. [CrossRef]

36. Pu, J.; Shen, C.; Zhang, C.; Liu, X. A semi-experimental method for evaluating frosting performance of air source heat pumps. Renew. Energy 2021, 173, 913-925. [CrossRef]

37. Kim, J.; Choi, H.-J.; Kim, K.C. A combined dual hot-gas bypass defrosting method with accumulator heater for an air-to-air heat pump in cold region. Appl. Energy 2015, 147, 344-352. [CrossRef]

38. Çakır, U.; Çomaklı, K.; Çomaklı, Ö.; Karslı, S. An experimental exergetic comparison of four different heat pump systems working at same conditions: As air to air, air to water, water to water and water to air. Energy 2013, 58, 210-219. [CrossRef]

39. Sarbu, I.; Sebarchievici, C. General review of ground-source heat pump systems for heating and cooling of buildings. Energy Build. 2014, 70, 441-454. [CrossRef]

40. Mitchell, M.S.; Spitler, J.D. Open-loop direct surface water cooling and surface water heat pump systems-A review. Heat. Vent. Air-Cond. Refrig. Res. 2013, 19, 125-140.

41. Schibuola, L.; Scarpa, M. Experimental analysis of the performances of a surface water source heat pump. Energy Build. 2016, 113, 182-188. [CrossRef]

42. Chen, X.; Zhang, G.; Peng, J.; Lin, X.; Liu, T. The performance of an open-loop lake water heat pump system in south China. Appl. Therm. Eng. 2006, 26, 2255-2261. [CrossRef] 
43. Klotzbücher, T.; Kappler, A.; Straub, K.L.; Haderlein, S.B. Biodegradability and groundwater pollutant potential of organic anti-freeze liquids used in borehole heat exchangers. Geothermics 2007, 36, 348-361. [CrossRef]

44. Dehghan, B. Experimental and computational investigation of the spiral ground heat exchangers for ground source heat pump applications. Appl. Therm. Eng. 2017, 121, 908-921. [CrossRef]

45. Yin, P.; Pate, M.; Battaglia, F. In-field performance evaluation and economic analysis of residential ground source heat pumps in heating operation. J. Build. Eng. 2019, 26, 100932. [CrossRef]

46. Han, C.; Ellett, K.M.; Naylor, S.; Yu, X.B. Influence of local geological data on the performance of horizontal ground-coupled heat pump system integrated with building thermal loads. Renew. Energy 2017, 113, 1046-1055. [CrossRef]

47. Urchueguía, J.F.; Zacarés, M.; Corberán, J.M.; Montero, Á.; Martos, J.; Witte, H. Comparison between the energy performance of a ground coupled water to water heat pump system and an air to water heat pump system for heating and cooling in typical conditions of the European Mediterranean coast. Energy Convers. Manag. 2008, 49, 2917-2923. [CrossRef]

48. Staffell, I.; Brett, D.; Brandon, N.; Hawkes, A. A review of domestic heat pumps. Energy Environ. Sci. 2012, 5, 9291-9306. [CrossRef]

49. Bucci, A.; Prevot, A.B.; Buoso, S.; De Luca, D.A.; Lasagna, M.; Malandrino, M.; Maurino, V. Impacts of borehole heat exchangers (BHEs) on groundwater quality: The role of heat-carrier fluid and borehole grouting. Environ. Earth Sci. 2018, 77, 175. [CrossRef]

50. Ahmadi, M.H.; Ahmadi, M.A.; Sadaghiani, M.S.; Ghazvini, M.; Shahriar, S.; Alhuyi Nazari, M. Ground source heat pump carbon emissions and ground-source heat pump systems for heating and cooling of buildings: A review. Environ. Prog. Sustain. Energy 2018, 37, 1241-1265. [CrossRef]

51. Naili, N.; Hazami, M.; Attar, I.; Farhat, A. In-field performance analysis of ground source cooling system with horizontal ground heat exchanger in Tunisia. Energy 2013, 61, 319-331. [CrossRef]

52. Guo, Y.; Zhang, G.; Zhou, J.; Wu, J.; Shen, W. A techno-economic comparison of a direct expansion ground-source and a secondary loop ground-coupled heat pump system for cooling in a residential building. Appl. Therm. Eng. 2012, 35, 29-39. [CrossRef]

53. Boban, L.; Miše, D.; Herceg, S.; Soldo, V. Application and design aspects of ground heat exchangers. Energies 2021, $14,2134$. [CrossRef]

54. Alshehri, F.; Beck, S.; Ingham, D.; Ma, L.; Pourkashanian, M. Techno-economic analysis of ground and air source heat pumps in hot dry climates. J. Build. Eng. 2019, 26, 100825. [CrossRef]

55. Noorollahi, Y.; Bigdelou, P.; Pourfayaz, F.; Yousefi, H. Numerical modeling and economic analysis of a ground source heat pump for supplying energy for a greenhouse in Alborz province, Iran. J. Clean. Prod. 2016, 131, 145-154. [CrossRef]

56. Wu, W.; Skye, H.M. Net-zero nation: HVAC and PV systems for residential net-zero energy buildings across the United States. Energy Convers. Manag. 2018, 177, 605-628. [CrossRef]

57. Bockelmann, F.; Fisch, M.N. It works-Long-term performance measurement and optimization of six ground source heat pump systems in Germany. Energies 2019, 12, 4691. [CrossRef]

58. Zhao, Z.; Shen, R.; Feng, W.; Zhang, Y.; Zhang, Y. Soil thermal balance analysis for a ground source heat pump system in a hot-summer and cold-winter region. Energies 2018, 11, 1206. [CrossRef]

59. Nouri, G.; Noorollahi, Y.; Yousefi, H. Designing and optimization of solar assisted ground source heat pump system to supply heating, cooling and hot water demands. Geothermics 2019, 82, 212-231. [CrossRef]

60. Sanz, A.; Fuente, R.; Martín, A.J. Solar hybrid PVT coupled heat pump systems towards cost-competitive NZEB. In Proceedings of the 12th International Conference on Solar Energy for Buildings and Industry, Rapperswil, Switzerland, 10-13 September 2018.

61. Huan, C.; Wang, F.; Li, S.; Zhao, Y.; Liu, L.; Wang, Z.; Ji, C. A performance comparison of serial and parallel solar-assisted heat pump heating systems in Xi'an, China. Energy Sci. Eng. 2019, 7, 1379-1393. [CrossRef]

62. Kong, X.; Sun, P.; Li, Y.; Jiang, K.; Dong, S. Experimental studies of a variable capacity direct-expansion solar-assisted heat pump water heater in autumn and winter conditions. Sol. Energy 2018, 170, 352-357. [CrossRef]

63. Huang, W.; Ji, J.; Xu, N.; Li, G. Frosting characteristics and heating performance of a direct-expansion solar-assisted heat pump for space heating under frosting conditions. Appl. Energy 2016, 171, 656-666. [CrossRef]

64. Kuang, Y.; Wang, R. Performance of a multi-functional direct-expansion solar assisted heat pump system. Sol. Energy 2006, 80, 795-803. [CrossRef]

65. Li, Y.-H.; Kao, W.-C. Taguchi optimization of solar thermal and heat pump combisystems under five distinct climatic conditions. Appl. Therm. Eng. 2018, 133, 283-297. [CrossRef]

66. Kamel, R.S.; Fung, A.S.; Dash, P.R. Solar systems and their integration with heat pumps: A review. Energy Build. 2015, 87, 395-412. [CrossRef]

67. Wang, E.; Fung, A.S.; Qi, C.; Leong, W.H. Performance prediction of a hybrid solar ground-source heat pump system. Energy Build. 2012, 47, 600-611. [CrossRef]

68. Wang, Q.; Ren, B.; Zeng, Z.; He, W.; Liu, Y.; Xiangguo, X.; Chen, G. Development of a novel indirect-expansion solar-assisted multifunctional heat pump with four heat exchangers. Build. Serv. Eng. Res. Technol. 2015, 36, 469-481. [CrossRef]

69. Panaras, G.; Mathioulakis, E.; Belessiotis, V. A method for the dynamic testing and evaluation of the performance of combined solar thermal heat pump hot water systems. Appl. Energy 2014, 114, 124-134. [CrossRef]

70. Panaras, G.; Mathioulakis, E.; Belessiotis, V. Investigation of the performance of a combined solar thermal heat pump hot water system. Sol. Energy 2013, 93, 169-182. [CrossRef] 
71. Youssef, W.; Ge, Y.; Tassou, S.A. Indirect expansion solar assisted heat pump system for hot water production with latent heat storage and applicable control strategy. Energy Procedia 2017, 123, 180-187. [CrossRef]

72. Bertsch, S.S.; Groll, E.A. Two-stage air-source heat pump for residential heating and cooling applications in northern US climates. Int. J. Refrig. 2008, 31, 1282-1292. [CrossRef]

73. Kim, D.H.; Park, H.S.; Kim, M.S. Optimal temperature between high and low stage cycles for R134a/R410A cascade heat pump based water heater system. Exp. Therm. Fluid Sci. 2013, 47, 172-179. [CrossRef]

74. Le, K.X.; Huang, M.J.; Shah, N.N.; Wilson, C.; Mac Artain, P.; Byrne, R.; Hewitt, N.J. Techno-economic assessment of cascade air-to-water heat pump retrofitted into residential buildings using experimentally validated simulations. Appl. Energy 2019, 250, 633-652. [CrossRef]

75. Xu, L.; Li, E.; Xu, Y.; Mao, N.; Shen, X.; Wang, X. An experimental energy performance investigation and economic analysis on a cascade heat pump for high-temperature water in cold region. Renew. Energy 2020, 152, 674-683. [CrossRef]

76. Jung, H.W.; Kang, H.; Yoon, W.J.; Kim, Y. Performance comparison between a single-stage and a cascade multi-functional heat pump for both air heating and hot water supply. Int. J. Refrig. 2013, 36, 1431-1441. [CrossRef]

77. Kwon, O.; Cha, D.; Park, C. Performance evaluation of a two-stage compression heat pump system for district heating using waste energy. Energy 2013, 57, 375-381. [CrossRef]

78. Safa, A.A.; Fung, A.S.; Kumar, R. Performance of two-stage variable capacity air source heat pump: Field performance results and TRNSYS simulation. Energy Build. 2015, 94, 80-90. [CrossRef]

79. Qu, M.; Abdelaziz, O.; Yin, H. New configurations of a heat recovery absorption heat pump integrated with a natural gas boiler for boiler efficiency improvement. Energy Convers. Manag. 2014, 87, 175-184. [CrossRef]

80. Sun, J.; Fu, L.; Zhang, S. A review of working fluids of absorption cycles. Renew. Sustain. Energy Rev. 2012, 16, 1899-1906. [CrossRef]

81. Yang, B.; Jiang, Y.; Fu, L.; Zhang, S. Experimental and theoretical investigation of a novel full-open absorption heat pump applied to district heating by recovering waste heat of flue gas. Energy Build. 2018, 173, 45-57. [CrossRef]

82. Boman, D.B. Adsorption Heat Pumps: Fundamentals and Applications; Springer Nature: Cham, Switzerland, 2021.

83. Demir, H.; Mobedi, M.; Ülkü, S. A review on adsorption heat pump: Problems and solutions. Renew. Sustain. Energy Rev. 2008, 12, 2381-2403. [CrossRef]

84. Núñez, T.; Mittelbach, W.; Henning, H.-M. Development of an adsorption chiller and heat pump for domestic heating and air-conditioning applications. Appl. Therm. Eng. 2007, 27, 2205-2212. [CrossRef]

85. Pensini, A.; Rasmussen, C.N.; Kempton, W. Economic analysis of using excess renewable electricity to displace heating fuels. Appl. Energy 2014, 131, 530-543. [CrossRef]

86. Moreno, P.; Castell, A.; Sole, C.; Zsembinszki, G.; Cabeza, L.F. PCM thermal energy storage tanks in heat pump system for space cooling. Energy Build. 2014, 82, 399-405. [CrossRef]

87. Kelly, N.J.; Tuohy, P.G.; Hawkes, A.D. Performance assessment of tariff-based air source heat pump load shifting in a UK detached dwelling featuring phase change-enhanced buffering. Appl. Therm. Eng. 2014, 71, 809-820. [CrossRef]

88. Psimopoulos, E.; Bee, E.; Luthander, R.; Bales, C. Smart control strategy for PV and heat pump system utilizing thermal and electrical storage and forecast services. In Proceedings of the ISES Solar World Congress 2017-IEA SHC International Conference on Solar Heating and Cooling for Buildings and Industry, Abu Dhabi, United Arab Emirates, 29 October-2 November 2017; pp. 2240-2251.

89. Gelleschus, R.; Böttiger, M.; Bocklisch, T. Optimization-based control concept with feed-in and demand peak shaving for a PV battery heat pump heat storage system. Energies 2019, 12, 2098. [CrossRef]

90. Sánchez, C.; Bloch, L.; Holweger, J.; Ballif, C.; Wyrsch, N. Optimised heat pump management for increasing photovoltaic penetration into the electricity grid. Energies 2019, 12, 1571. [CrossRef]

91. Wu, W.; Skye, H.M.; Domanski, P.A. Selecting HVAC systems to achieve comfortable and cost-effective residential net-zero energy buildings. Appl. Energy 2018, 212, 577-591. [CrossRef] [PubMed]

92. Martin-Escudero, K.; Salazar-Herran, E.; Campos-Celador, A.; Diarce-Belloso, G.; Gomez-Arriaran, I. Solar energy system for heating and domestic hot water supply by means of a heat pump coupled to a photovoltaic ventilated façade. Sol. Energy 2019, 183, 453-462. [CrossRef]

93. Jarre, M.; Noussan, M.; Simonetti, M. Primary energy consumption of heat pumps in high renewable share electricity mixes. Energy Convers. Manag. 2018, 171, 1339-1351. [CrossRef]

94. Badache, M.; Ouzzane, M.; Eslami-Nejad, P.; Aidoun, Z. Experimental study of a carbon dioxide direct-expansion ground source heat pump (CO2-DX-GSHP). Appl. Therm. Eng. 2018, 130, 1480-1488. [CrossRef]

95. American Society of Heating, R.; Air-Conditioning Engineers, I. 2017 ASHRAE ${ }^{\circledR}$ Handbook—Fundamentals (SI Edition); American Society of Heating, Refrigerating and Air-Conditioning Engineers, Inc. (ASHRAE): Atlanta, GA, USA, 2018. 